\title{
Cash Management in the Travel and Leisure Sector: Evidence from the United Kingdom
}

\section{Wisal Ahmad}

Submitted to the

Institute of Graduate Studies and Research

in partial fulfillment of the requirements for the degree of

Doctor of Philosophy

in

Finance

Eastern Mediterranean University

July 2018

Gazimağusa, North Cyprus 
Approval of the Institute of Graduate Studies and Research

Assoc. Prof. Dr. Ali Hakan Ulusoy Acting Director

I certify that this thesis satisfies all the requirements as a thesis for the degree of Doctor of Philosophy in Finance.

Assoc. Prof. Dr. Nesrin Ozatac

Acting Chair, Department of Banking and Finance

We certify that we have read this thesis and that in our opinion it is fully adequate in scope and quality as a thesis for the degree of Doctor of Philosophy in Finance.

Prof. Dr. Cahit Adaoglu

Supervisor

Examining Committee

1. Prof. Dr. Cahit Adaoglu

2. Prof. Dr. Eralp Bektas

3. Prof. Dr. Mustafa Besim

4. Prof. Dr. Mehmet Ivrendi

5. Prof. Dr. Ibrahim Hakan Yetkiner 


\begin{abstract}
This thesis investigates the determinants of cash holdings for companies operating in the travel and leisure sector of the United Kingdom (UK) between 2005 and 2016. Following the predictions of three prominent models, namely, the pecking order model, the trade-off model and the free cash flow model, the study tests the hypotheses for several firm-specific determinants of cash holdings. The study finds that size, growth opportunities and cash flow affect cash holdings positively, while leverage, capital expenditures, liquidity, cash flow volatility and dividend payments affect negatively. Consequently, it can be concluded that the pecking-order model receives strong empirical support followed by trade-off model to explain the variation in cash holdings among travel and leisure companies of UK. The free cash flow model receives only weak support. Moreover, at the sub-sector level, companies operating in the airlines sub-sector hold more cash than the reference sub-sector of travel and tourism.
\end{abstract}

Keywords: cash; determinants; travel and leisure; tourism; United Kingdom. 


\section{ÖZ}

Bu tez, 2005 ve 2016 yılları arasında Birleşik Krallığı'nın seyahat ve eğlence sektöründe faaliyet gösteren şirketlerin nakit oranlarını araştırmaktadır. Bu araştırma yapılırken, finansal hiyerarşi, dengeleme ve serbest nakit akışı modelleri kullanılarak, nakit oranını belirleyen şirket özgü faktörler için hipotezler test edilmiştir. Çalışmada, büyüklük, büyüme fırsatları ve nakit akışının şirketlerin nakit oranını olumlu yönde; kaldıraç, sermaye harcamaları, likidite, nakit akışı dalgalanması ve temettü ödemelerinin ise olumsuz yönde etkilediği tespit edilmiştir. Finansal hiyerarşi modeli seyahat ve eğlence şirketlerinin nakit oranını güçlü bir ampirik destekle açıklamaktadır. Dengeleme modeli ikinci sırada seyahat ve eğlence şirketlerinin nakit oranını açıklamaktadır. Tezde, serbest nakit akışı modeli için zayıf bir ampirik destek bulunmuştur. Ayrıca, alt sektör seviyesinde, havayolları şirketleri, seyahat ve turizm referans alt sektöründen daha fazla nakit bulundurmaktadır.

Anahtar Kelimeler: nakit; faktörler; seyahat ve eğlence; turizm; Birleşik Krallık. 


\section{ACKNOWLEDGEMENT}

I would like to record my gratitude to Prof. Dr. Cahit Adaoglu for his supervision, advice, and guidance from the very early stage of this thesis as well as giving me extraordinary experiences throughout the work. Above all and the most needed, he provided me constant encouragement and support in various ways. His ideas, experiences and passions have truly inspired and enriched my growth as a student. I am indebted to him more than he knows.

Besides, a number of friends had always been around to support me morally. I would like to thank them as well. Moreover, I owe quite a lot to my family, especially my wife, who allowed me to travel all the way from Pakistan to Cyprus and supported me all throughout my studies. I would like to dedicate this study to them as an indication of their significance in this study as well as in my life. 


\section{TABLE OF CONTENTS}

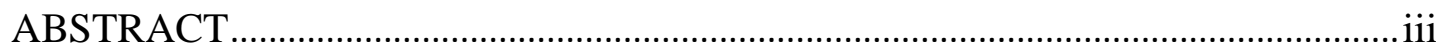

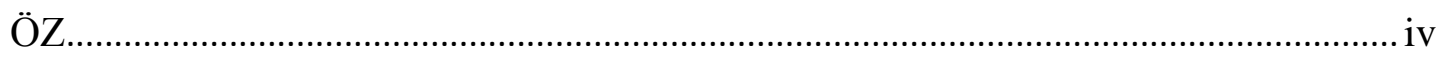

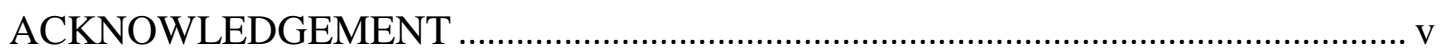

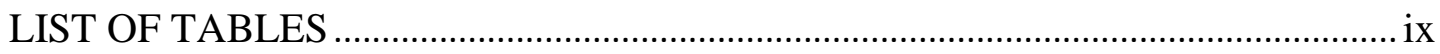

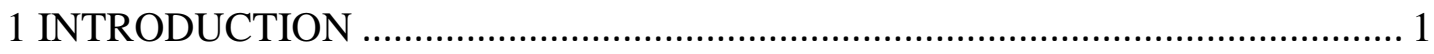

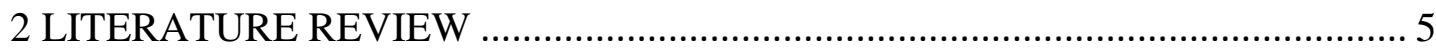

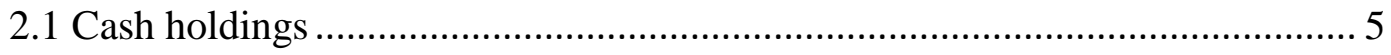

2.2 Theoretical models .................................................................................... 7

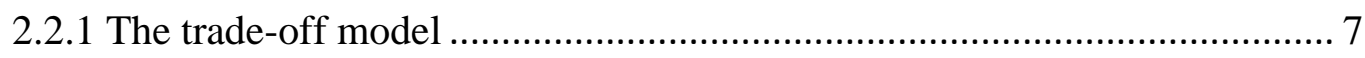

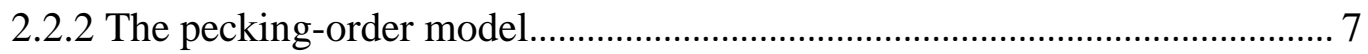

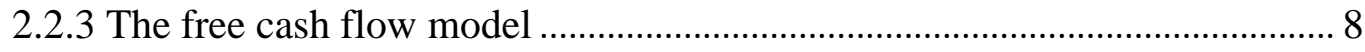

2.2.4 Determinants of cash holdings and hypotheses ......................................... 8

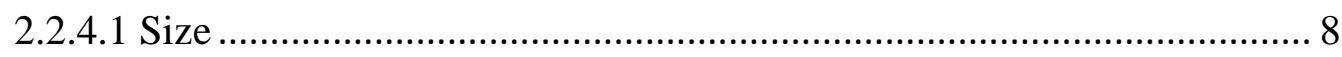

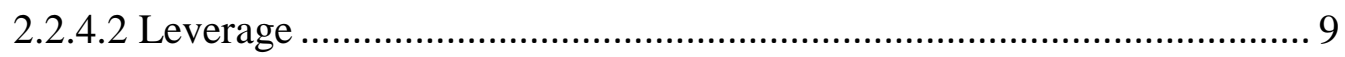

2.2.4.3 Capital expenditures ......................................................................... 10

2.2.4.4 Growth opportunities............................................................................ 11

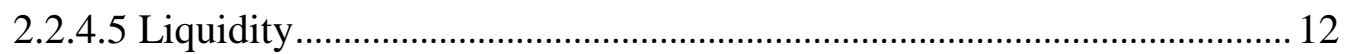

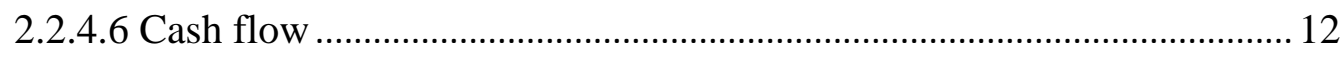

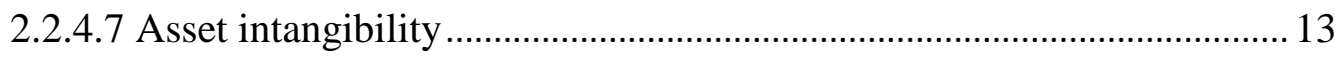

2.2.4.8 Cash flow volatility .............................................................................. 14

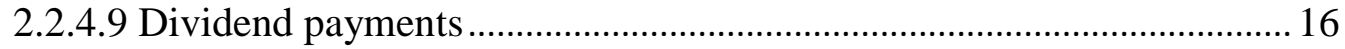

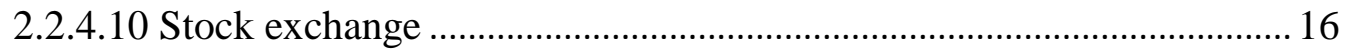

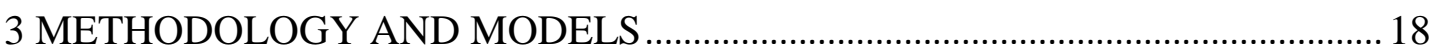




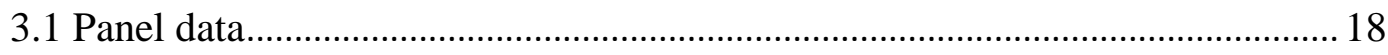

3.2 Regression analyses and models ................................................................... 19

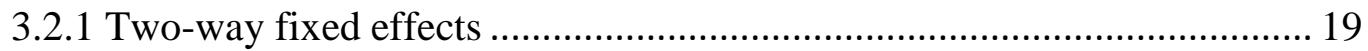

3.2.2 Generalized method of moments (GMM) ......................................................2.

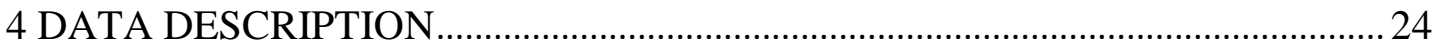

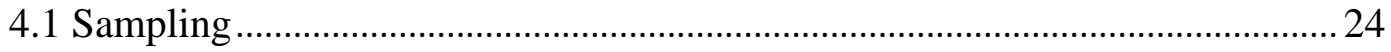

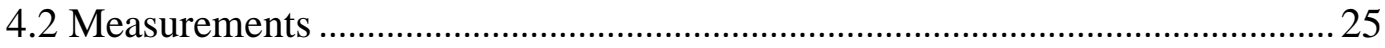

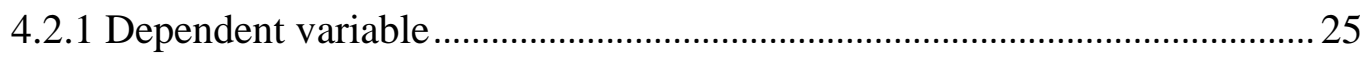

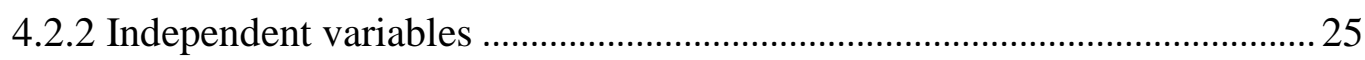

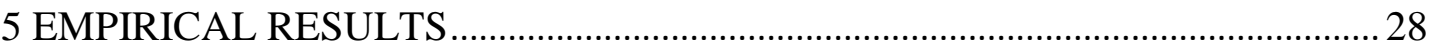

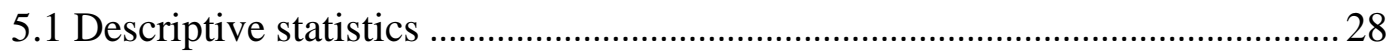

5.2 Two-way fixed effects estimation .................................................................... 30

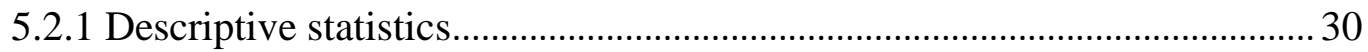

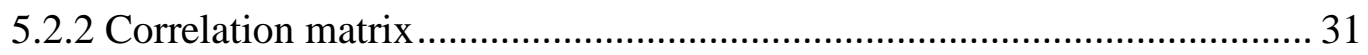

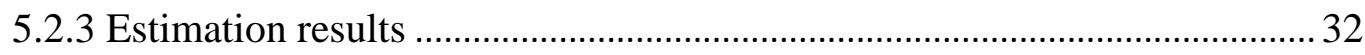

5.3 Generalized method of moments (GMM) estimation....................................... 35

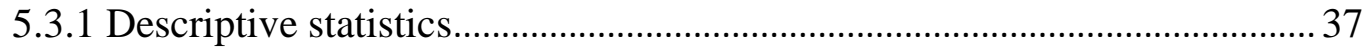

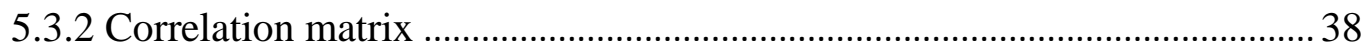

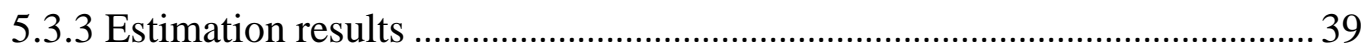

5.4 Argumentative explanations and comparative analysis ................................. 42

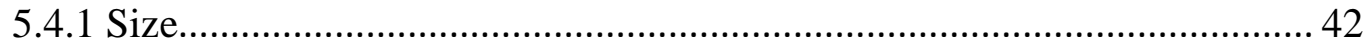

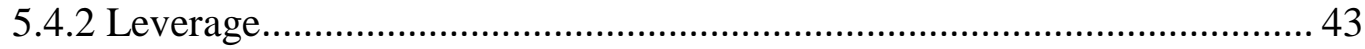

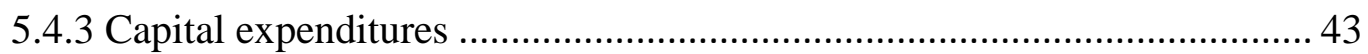

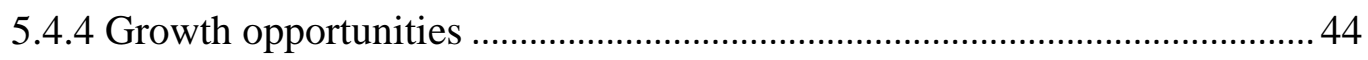

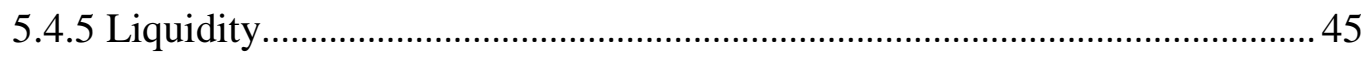




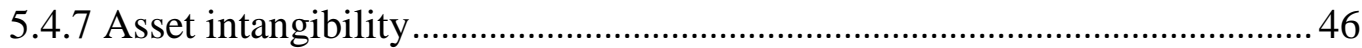

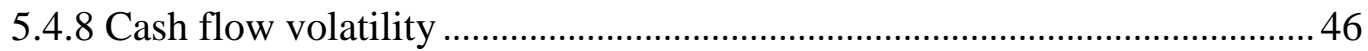

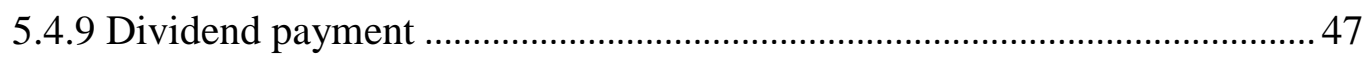

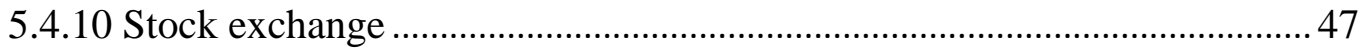

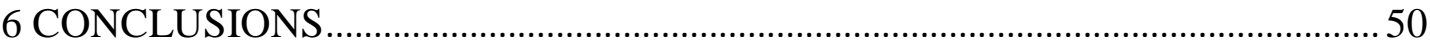

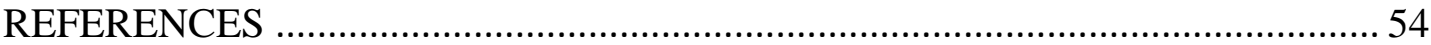




\section{LIST OF TABLES}

Table 1. Definitions of determinants and the respective abbreviations

Table 2. Descriptive statistics of cash holdings over 2005-2016: Travel and leisure sector, and its sub-sectors

Table 3. Descriptive statistics (Two-way fixed effects) ....................................... 31

Table 4. Pearson correlation matrix (Two-way fixed effects) .................................. 32

Table 5. Estimation results (Two-way fixed effects) ............................................... 34

Table 6. Sub-Sector, sample time period and sub-period effects...................36

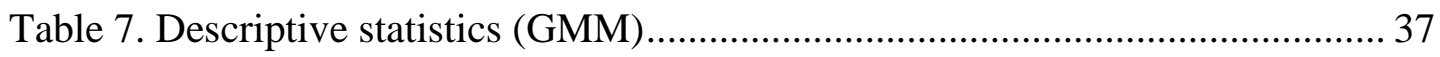

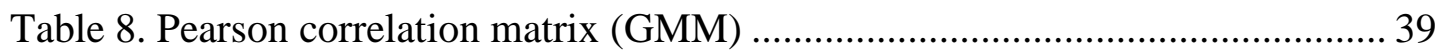

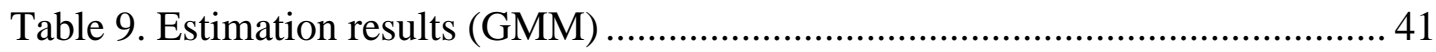




\section{Chapter 1}

\section{INTRODUCTION}

The unique fundamental characteristics of companies operating in the travel and leisure sector provide basis for investigating financial management theories and business practices. In general, the empirical studies investigate the current theories by incorporating the unique central attributes of travel and leisure sector to fabricate managerial and financial implications for practitioners employed in this sector. ${ }^{1}$ Singal (2015) argues that companies operating in the hospitality and tourism sector not only have high leverage, high risk, high capital intensity, but also face high competition relative to other sectors. Furthermore, Singal (2015) argues that these variations in the fundamental attributes provide basis for investigating business theories and practices in the context of hospitality and tourism sector, which will not only affect the managerial, financial and social conduct of travel and leisure companies but will also help in explaining the survival of these companies.

The hospitality finance literature is enriched with unique central attributes of travel and leisure companies. Companies in travel and leisure sector are not only constrained by various confining debt covenants but are also massively leveraged (e.g., Karadeniz et al., 2009; Kwansa et al., 1987; Sheel, 1998). Companies operating

\footnotetext{
${ }^{1}$ For instance, Dewally et al. (2013) examine the stock performance of companies in the hospitality sector. Karadeniz et al. (2009) examine the determinants of capital structure in Turkish lodging companies and test the validity of traditional capital structure theories for this sector. Delbar and Upenja (2007) examine the dividend policy in the U.S restaurant sector. Kim and Gu (2009) study the financial features of dividend paying firms in the hospitality industry. Sheel (1994) studies the determinants of capital structure for the hotel companies and compares them to the capital structures of manufacturing companies.
} 
in travel and leisure sector are generally highly competitive, small in size and bear high fixed cost, high capital expenditures, high cash flow volatility and low operating margins and cash holdings (e.g., Kim and Gu, 2009; Singal, 2015; Upenja and Delbar, 2001).

Companies hold cash and cash equivalents to meet their liquidity needs. The empirical examination of the determinants of cash holdings in various sectors and countries has received significant attention in the literature. ${ }^{2}$ Similarly, this empirical study examines the determinants of cash holdings of companies operating in the travel and leisure sector of the United Kingdom (UK), and its sub-sectors. Notably, there is no empirical study examining the cash holdings of companies operating in the UK travel and leisure sector, which contributes considerably to the UK economy. In the 2016 United Nations World Tourism Organization report, UK stands $8^{\text {th }}$ amongst the top ten tourist's destination around the world, and has international tourists of 34.4 million generating $\$ 45.5$ billion for the economy. ${ }^{3}$ Moreover, there is a considerable number of travel and leisure publicly listed companies in the UK relative to other countries, and this provides another justification for selecting it as a sample country.

To examine the cash holdings management, the fundamental characteristics of travel and leisure sector must be considered. Capital expenditures are of acute importance as the sector heavily relies on tangible (e.g., land, buildings, and equipment) and intangible assets (e.g., labor, goodwill, brand recognition,

${ }^{2}$ For instance, see Lee and Powell (2011) for Australia, Hardin et al. (2009) and Kim et al. (2011) for the United States, Ozkan and Ozkan (2004) for the United Kingdom, Pastor and Gama (2013) for Portugal and Uyar and Kuzey (2014) for Turkey.

${ }^{3}$ The set of information is retrieved from http://www.eunwto.org/doi/pdf/10.18111/9789284418145. 
information technology and software). In the financial literature, capital expenditures is a prominent explanatory variable used in empirical studies focusing on cash holdings (Opler et al., 1999; Ferriera and Vilela, 2004, Kim et al., 2011, Kim et al., 2013). The travel and leisure sector is characterized by growth prioritizing and high capital expenditures. Cash is used to fund these capital expenditures (Kim et al., 2011; Kim and Gu, 2009) and profitable growth opportunities (Kim et al., 2013). The unique characteristics of cyclicality, high leverage, high risk, high capital intensity and high competitiveness, make the cash holdings policy an important financial management decision for managers and investors in the travel and leisure sector.

In the literature, the three prominent models, namely, the pecking order model, the trade-off model and the free cash flow model, can be applicable for the companies operating in the travel and leisure sector and can explain the differences amongst its six sub-sectors. Within the frameworks of these three theoretical models and the general characteristics of the travel and leisure sector, this study explores the determinants of corporate cash holdings in the travel and leisure sector and its six sub-sectors in the UK. The six sub-sectors are airlines, gambling, hotels, recreational services, restaurants and bars, and travel and tourism. This study uses STATA econometrics software to estimate the two-way fixed effects and generalized method of moments (GMM) to investigate the impact of explanatory variables on the cash holdings. Panel data set winsorized at $1 \%$ level is extracted from 51 companies of travel and leisure sector of UK between 2005-2016. The study shows that size, growth opportunities and cash flow affect cash holdings positively, while leverage, capital expenditures, liquidity, cash flow volatility and dividend payments affect negatively. Consequently, it can be concluded that pecking-order model receives strong empirical support followed by trade-off model to explain the variation in cash 
holdings among travel and leisure companies of UK. The free cash flow model receives only weak support. Moreover, at the sub-sector level, companies operating in the airlines sub-sector hold more cash than the reference sub-sector of travel and tourism.

The rest of the thesis is organized as follows: Section 2 presents the literature review, the development of hypotheses, and the definitions of variables. Section 3 describes the data and methodology followed by measurement of variables in Section 4. The results of the regression analyses are presented and discussed in Section 5. Section 6 concludes the thesis. ${ }^{4}$

\footnotetext{
${ }^{4}$ Some results of this thesis are published in: Wisal Ahmad \& Cahit Adaoglu. Cash management in the travel and leisure sector: evidence from the United Kingdom, Forthcoming in Applied Economics Letters, DOI: 10.1080/13504851.2018.1488050
} 


\section{Chapter 2}

\section{LITERATURE REVIEW}

This chapter reviews the extant body of literature, based on cash holdings studies. The section also discusses the concept of cash holdings and its benefits and costs, followed by explanation of three theoretical models: trade-off model, peckingorder model and free cash flow model. Finally, hypotheses are developed following the predictions of three theoretical models mentioned above. Moreover, this chapter does not have a separate literature review section, rather it incorporates the literature review based on the content of the chapter sections.

\subsection{Cash holdings}

Cash is a crucial component for the day-to-day operations of every company. It provides the firm with liquidity and it facilitates the payment of various types of obligations. Without sufficient liquid assets a company will not be able to meet those obligations and hence it will be forced to declare bankruptcy, sooner or later. In the literature, non-US empirical studies examining the determinants of corporate cash holdings in the travel and leisure sector as a whole and its sub-sectors do not exist. For instance, Kim et al. (2011) examine the determinants of cash holdings for the restaurant sector in the US. Subsequently, Kim et al. (2013) analyze the financial characteristics of cash-rich and cash-poor restaurant companies in the US. Kim et al. (2011, p. 569) stress that the restaurant sector is not only characterized by growth prioritization but also asset- and labor-intensity. Similarly, Kim and Gu (2009) state that "[US] Hospitality firms are fixed assets-intensive and investment opportunities 
would require large amounts of new capital” (p. 364). Mung and Jang (2015) examine working capital, cash holdings and profitability of the restaurant companies in the US. Recently, Dogru and Sirakaya-Turk (2017) examine the value of cash holdings in hotel companies in the US.

Companies must hold cash and cash equivalents to meet their liquidity needs. It enables companies to meet several kinds of payment obligations. Therefore, managers are required to hold cash to take on future uncertainties regardless of whether they are managing private or public companies. In the financial literature, cash holdings are commonly defined as cash and cash equivalents to total net assets (Drobetz and Grüninger, 2007). Cash equivalents (short-term investments, petty cash, checks received but not yet deposited, saving accounts) are current assets, which can be easily converted into cash and are regarded as a major source of liquidity. Ferreira and Vilela (2004) argue that these securities bear low return as they are characterized by low risk.

Holding cash bears both benefits and costs, depending upon how much cash is kept. Holding too much idle cash incurs opportunity costs by losing lucrative investment opportunities. While, keeping more cash leads to agency problems between company's management and shareholders (Jensen, 1986). On the other hand, holding too much cash keeps companies from facing financial distress. On the other hand, holding less cash may benefit companies by avoiding opportunity costs and agency problems, but such companies are more vulnerable to financial distress. Therefore, an optimal level of cash holdings is desired to balance these costs and benefits.

In case of perfect capital market, the need for holding cash would become irrelevant, as companies would be able to raise funds easily. But, as in the real world, 
there is no existence of perfect capital market, which creates ambiguities about the level of cash holdings (Drobetz and Grüninger, 2007). Therefore, following the financial literature, some theoretical models have been developed to explain the variation in levels of cash holdings across companies.

\subsection{Theoretical models}

\subsubsection{The trade-off model}

The trade-off model states that companies need to balance the marginal benefits and costs of keeping cash to maintain an optimal level of cash (Al-Najjar and Belghitar, 2011). Keeping cash incurs costs such as opportunity cost and low return (Ferreira and Vilela, 2004). However, keeping cash does render benefits which are derived from two motives. First, the precautionary motive of holding cash helps companies to avoid the menace of financial distress, and holding cash reserves also enables them to grab profitable investment opportunities (Hardin et al., 2009). Second, the transaction motive enables companies to mitigate the significant transaction costs of obtaining external financing due to information asymmetries between insiders and outsiders (Myers and Majluf, 1984; Ferreira and Vilela, 2004). Companies with higher agency costs of debt face higher transactions costs of getting external financing (Jensen and Meckling, 1976). Therefore, companies with high cash shortage incur higher transaction costs in getting external funds and tend to hold more cash.

\subsubsection{The pecking-order model}

The pecking-order model states that companies prefer to hold cash due to the presence of asymmetric information between insiders and outsiders. The magnitude of information asymmetry is detrimental in external financing costs (Myers and Majluf, 1984). Therefore, managers first utilize internal financing options for 
financing their capital expenditures to mitigate the higher costs of external financing. In case of a financial deficit, they reach out to external financing options and prefer to use the debt financing first and ultimately, equity financing (Ferreira and Vilela, 2004).

\subsubsection{The free cash flow model}

Holding excessive cash results in low returns and agency costs for shareholders (Jensen 1986). The free cash flow model states companies may not hold an optimal level of cash, and managers tend to hold excessive cash for their private benefits and in the pursuit of empire-building motives through wealth destroying mergers and acquisitions (Easterbrook, 1984; Jensen, 1986). Stockpiling cash by managers may lead to agency conflicts and may resultantly undercut corporate value (Jensen, 1986). Managers in pursuit of their own interests exploit shareholders, particularly minority shareholders who have little say in managerial decisions (Jensen, 1986; Jensen and Meckling, 1976). The free cash model argues that any excess cash flow should be returned to shareholders.

\subsubsection{Determinants of cash holdings and hypotheses}

\subsubsection{Size}

Firm size is a significant determinant in the cash holding studies. Larger companies raise funds cheaper than smaller ones do (Peterson \& Rajan, 2002). Larger companies are more diversified, have less financial distress costs, and enjoy the benefits of economic scale in both operations and external financing (Al-Najjar and Belghitar, 2011). Small companies tend to keep more cash to shun the possibility of financial distress if a company's size is regarded as a token of financial distress (Ozkan and Ozkan, 2004). There is a negative link between size and cash holdings, supporting the trade-off theory (Pastor and Gama, 2013). Moreover, within the 
framework of pecking order model, it is assumed that larger companies are more successful and after making investments, such companies need to hold more cash (Ferreira and Vilela, 2004). Furthermore, larger companies are more diversified and managers of these companies are more flexible in devising the financial policies and keep excessive cash.

Similarly, the free cash flow model also predicts a positive relationship between size and cash holdings. Larger companies typically have a widely dispersed ownership structure resulting in weaker monitoring and higher agency problems. In large companies, managers have more discretionary managerial power and hence, tend to hold excessive cash (Ferreira and Vilela, 2004). In the literature, Bigelli and Sánchez-Vidal (2012), Hardin et al. (2008), Al-Najjar and Belghitar (2011), and Ferreira and Vilela (2004) find a negative link between cash holdings and size. In this study, both positive and negative effects are expected for UK companies operating in the travel and leisure sector and the following hypothesis is proposed.

H1: There is a positive or negative relationship between cash holdings and size for companies operating in the travel and leisure sector.

\subsubsection{Leverage}

Companies use financial leverage as a viable alternative for liquid assets (Maheshwari and Rao, 2017). Particularly, companies having easy access to debt markets hold less cash (Al-Najjar and Belghitar, 2011; D’Mello et al., 2008). Furthermore, leveraged companies keep less cash due to being monitored closely by lenders (Ferreira and Vilela, 2004). Numerous empirical studies find a negative relationship between financial leverage and cash holdings (e.g., Kim et al., 2011; Lian, Sepehri and Foley, 2011; Ozkan and Ozkan, 2004). A contrary argument states that highly levered companies keep more cash under their control to overcome the 
increased risk of default and bankruptcy (Islam, 2012). Hence, under the predictions of the trade-off model, the relationship between leverage and cash holdings is both positive and negative.

Following the financing hierarchy of the pecking-order model, as the degree of investment exceeds the amount of retained earnings, the level of cash holdings decreases with an increase in the amount of debt (Ferreira and Vilela, 2004). Thus, the pecking-order model predicts a negative relationship between leverage and cash holdings. The free cash flow model also predicts a negative relationship, since higher leverage act as an effective monitoring mechanism, rendering less discretionary powers to managers over the use of funds. The travel and leisure sector is characterized by high growth, high fixed costs, asset intensive, and high financing needs. These characteristics make the leverage effect on cash holdings significant for companies operating in the travel and leisure sector. Leverage is expected to be an alternative source for cash in this sector. The following hypothesis is proposed:

H2: There is a positive or negative relationship between cash holdings and leverage for companies operating in the travel and leisure sector.

\subsubsection{Capital expenditures}

Travel and leisure companies are capital intensive (Singal, 2015). However, capital intensity differs among the sub-sectors. For instance, hotels and airlines are more capital intensive than restaurants sub-sector (Reich, 1993). Companies with higher capital expenditures keep less cash since capital expenditures can lead to higher profitability, easier and cheaper access to debt financing (Maheshwari and Rao, 2017). Kim et al. (2013) and Bates et al. (2009) posit that capital expenditures enable companies to acquire tangible assets, and such assets can be pledged as 
collateral for borrowing. Hence, higher borrowing capacity mitigates the need for maintaining cash reserves.

Conversely, companies with higher capital expenditures tend to hold more cash as capital expenditure signals growth opportunities and financial distress (Riddick and Whited, 2009) and supports the trade-off model. Similarly, Opler et al. (1999) find a positive relationship between capital expenditures and cash holdings. However, there is extensive empirical evidence supporting the negative relationship between capital expenditures and cash holdings (e.g., Kim et al., 2011; Uyar and Kuzey, 2014). Similarly, the effect of capital expenditures on cash holdings is expected to be strong as the travel and leisure sector is asset intensive and has high capital expenditures. The following hypothesis is proposed:

H3: There is a negative relationship between cash holdings and capital expenditures for companies operating in the travel and leisure sector.

\subsubsection{Growth opportunities}

Companies with more growth opportunities keep more cash to take on lucrative future ventures (Garcia-Teruel and Martinez-Solano, 2008, Uyar and Kuzey, 2014). The positive effect of growth opportunities on cash holdings supports the argument that companies need to keep more cash to save on opportunity costs in tapping new profitable projects (Uyar and Kuzey, 2014). Companies with higher

growth opportunities hold cash to avoid liquidity shortages (Hardin et al., 2009). Several studies support the precautionary motive of trade-off theory and find a positive relationship between cash holdings and growth opportunities (e.g., Kim et al., 2011; Kim et al., 2013; Uyar and Kuzey, 2014).

Similarly, the pecking order model predicts a positive relationship and companies keep more cash to avoid the adverse selections costs of external financing 
for projects. However, the free cash flow model predicts a negative relationship between growth opportunities and cash holdings. Ferreira and Vilela (2004) argue that entrenched managers in companies with poor growth opportunities tend to stockpile cash and invest in negative NPV projects, ultimately undercut company value. The effect of growth opportunities on cash holdings is expected to be strong as the travel and leisure sector bears high capital intensity, high risk and high competitiveness. The following hypothesis is proposed:

H4: There is a positive relationship between cash holdings and growth opportunities for companies operating in the travel and leisure sector.

\subsubsection{Liquidity}

Apart from cash, liquid assets can be used as a substitute for cash (Al-Najjar and Belghitar, 2011). Companies having more liquidity or liquid asset substitutes hold less cash (Uyar and Kuzey, 2014). Moreover, companies facing cash shortages can easily and cheaply convert liquid asset substitutes into cash (Ozkan and Ozkan, 2004). Numerous empirical studies find a negative relationship between cash holdings and liquidity (e.g., Lian et al., 2011; Uyar and Kuzey, 2014) and support the prediction of trade-off model. Similarly, the negative liquidity effect holds for the cyclical, asset- intensive and growth-prioritizing travel and leisure sector. The following hypothesis is proposed:

H5: There is a negative relationship between cash holdings and liquidity for companies operating in the travel and leisure sector.

\subsubsection{Cash flow}

According to Jensen (1986), managers tend to hold excessive cash to achieve autonomy in managerial decisions for their private benefits. Managers face intense pressure from borrowers to finance new projects (Jensen, 1986; Hardin et al., 2009). 
Therefore, high cash flows from operations help managers to fund these projects lowering need for holding cash, which supports the trade-off model. Hardin et al. (2009) and Kim et al. (2013) find a negative relationship between cash holdings and cash flows.

Conversely, companies with higher cash flows tend to stockpile cash (Drobetz and Grüninger, 2007) and possess the ability to save more (Lian et al., 2011). Supporting the pecking-order model, companies with high cash flows tend to hold more cash to grab growth opportunities and to provide for prospective contingencies (Opler et al., 1999). In line with the pecking order model, D’Mello et al. (2008) argue that internally generated finances are preferred over the costly external funds for fulfilling financial obligations of the company. Numerous empirical works find a positive relationship between cash holdings and cash flows (e.g., Ferreira and Vilela, 2004; Ozkan and Ozkan 2004). The effect of cash flow on cash holdings is expected to be strong in the travel and leisure sector, particularly due to the capital-, asset- and growth- intensive characteristics. In general, such characteristics make the sector a financially constrained sector. Hence, the following hypothesis is proposed:

H6: There is a positive relationship between cash holdings and cash flow for companies operating in the travel and leisure sector.

\subsubsection{Asset intangibility}

Intangible capital has been regarded as an imperative part of corporate cash holdings studies (Antonio et al., 2013). The study done by Antonio et al. (2013) supports the precautionary motive of trade-off theory and finds a positive relationship between cash holdings and asset intangibility. The intangible assets can reduce the borrowing capacity of companies since they carry less collateral value, 
uncertain liquidation value, and higher information asymmetry (e.g., Williamson, 1988; Holthausen and Watts, 2001; Shleifer and Vishny, 1992). This can lead to operational and financial inflexibility and these companies tend to hold more cash.

Conversely, Martínez-Sola, Garcia-Teruel and Martínez-Solano (2011) finds a negative relationship between cash holdings and asset intangibility. The relationship can also be negative due to the remarkable advances in information and communication technologies. Peculiarly, in the recent times, companies have gradually started investing more in intangibles assets to not only increase their uniqueness but also to improve their competitive advantage (Lev, 2000; Nakamura, 2001). The travel and leisure sector has witnessed numerous information technology progresses over the past decades (Ip, Leung and Law, 2011). Customers of travel and leisure sector demand more technology-intensive services (Gursoy and Swanger, 2007). Furthermore, internet gambling has started to pop up as countries are getting more advanced in technology and is growing quite swiftly (Griffiths and Parke, 2002). Therefore, gambling companies are more dependent on intangible assets and have become more technology-, service- and internet-oriented. Hence, companies operating in travel and leisure sector can gain competitive advantage to become more profitable due to the effective implementation of information and communication technologies and tend to hold less cash. However, in the intangible asset intensive travel and leisure sector, the need for high, continuous and up-to-date intangible asset expenditures is high and can drive companies to hold more cash.

H7: There is a positive or negative relationship between cash holdings and asset intangibility for companies operating in the travel and leisure sector.

\subsubsection{Cash flow volatility}


The role of cash becomes significant in times of hard business settings to absorb detrimental shocks and to survive in situations of uncertainty. Companies facing more variability in cash flows are highly exposed to cash shortages (Ozkan and Ozkan, 2004). Financially constrained companies with more variability in cash flows create uncertainty about level of cash holdings in future (Han and Qiu, 2007). Companies facing variability in cash flows tend to lose lucrative investment opportunities (Minton and Shrand, 1990). Several empirical studies support the precautionary motive of trade-off theory and find a positive relationship between cash holdings and cash flow variability (e.g., Al-Najjar and Belghitar, 2011; Bigelli and Sánchez-Vidal, 2012; Lee and Powell, 2011).

Conversely, Ferreira and Vilela (2004) and Paskelian et al. (2010) find a negative relationship between cash holdings and cash flow variability. The negative relationship may be explained by the argument that increased cost of capital and agency costs are related with high cash flow volatility (Ferreira and Vilela, 2004). Companies which are characterized by high cost of capital could not hold cash because the cost of holding cash is higher than the cash flows generated by that cash (Ferreira and Vilela, 2004). Hence, it is very costly for the companies with high cost of capital to hold cash for precautionary motives. Moreover, following the empirical findings of Ozkan and Ozkan (2004) and Uyar and Kuzey (2014), the relationship between cash holdings and cash flow volatility remains inconclusive. The effect of cash flow variability on cash holdings is expected to be strong in the cyclical, high risk and high competitive travel and leisure sector. The following hypothesis is proposed:

H8: There is a positive or negative relationship between cash holdings and cash flow volatility for companies operating in the travel and leisure sector. 


\subsubsection{Dividend payment}

Companies that pay stable dividends hold less cash and can obtain cheaper funds when required (Al-Najjar and Belghitar, 2011). Conversely, companies can keep more cash as a precautionary motive to pursue the dividend stability policy (Maheshwari and Rao, 2017; Ozkan and Ozkan, 2004). Financially constrained or highly leveraged companies find it onerous to raise further debt. By reducing their dividends, such companies may uplift their retained earnings to provide for cash requirements.

Kim et al. (2011) and Bates et al. (2009) find a negative relationship between cash holdings and dividend payments while a positive relationship is found by Bigelli and Sánchez-Vidal (2012) and Drobetz and Grüninger (2007). In the cyclical, high risk and high capital expenditures sector such as the travel and leisure, it is expected that companies operating in this sector are more likely to be financially constrained. A dividend dummy variable (DIVD) is used to capture this relationship. Accordingly, the following hypothesis is proposed:

H9: There is a negative relationship between cash holdings and dividend payment dummy for companies operating in the travel and leisure sector.

\subsubsection{Stock exchange}

In the Main Market of the London Stock Exchange (Main-LSE), wellestablished and larger companies of travel and leisure sector are traded, and such companies have easier access to domestic and international funds coupled with a knowledgeable investor base and a poised regulatory atmosphere. However, in the Alternative Investment Market of London Stock Exchange (AIM-LSE) and InterCapital Securities and Derivative Exchange (ISDX), small and medium size companies of travel and leisure sector are traded. Based on the fundamental 
characteristics of high risk, high competitiveness, asset- and labor-intensiveness and growth-prioritization, the travel and leisure sector companies that are traded in the Main-LSE are expected to hold more cash. Conversely, companies listed on MainLSE are normally larger in size and have easier access to domestic and international capital markets to raise funds and tend to hold less cash. A stock exchange dummy variable (STEX) is used to capture this relationship. The following hypothesis is proposed:

H10: There is positive or negative relationship between cash holdings and the stock exchange dummy for the companies operating in the travel and leisure sector. 


\section{Chapter 3}

\section{METHODOLOGY AND MODELS}

This chapter defines panel data and explains its advantages and disadvantages. Furthermore, the chapter presents the research methods employed in the study and explains the regression analyses. Moreover, the detailed explanations for the variables are discussed in the following chapter.

\subsection{Panel data}

In this study, panel or longitudinal data is used, which is collected from different companies over multiple time periods. Panel data carries both aspects of cross-sectional and time-series data. The cross-sectional aspect shows that observations are made at a point in time across multiple units (companies), while time-series aspect is given by the successive measurement of the same unit over a time period. The advantage of panel data is that the study of cross section over multiple time periods results in increased number of observations, followed by increased degree of freedom, allowing researchers to include more explanatory variables in their model (Verbeek, 2008). This helps to control for collinearity among the explanatory variables. Furthermore, panel data is more appropriate for more intricate dynamic models than cross-sectional data. Hence, panel data shows how individuals or companies change over time, while cross-sectional data provides information about individuals at a particular point in time (Wooldridge, 2002).

The drawbacks of panel dataset include problems of multicollinearity and autocorrelation that prevails among cross sections and time series, which need to be 
fixed. Furthermore, panel data often carries missing observations as companies merge or go bankrupt.

\subsection{Regression analyses and models}

The research methodologies employed in this study to perform regression analyses for the panel dataset are Two-way fixed effects and Generalized method of moments (GMM) as follows:

\subsubsection{Two-way fixed effects}

The two-way fixed effects regression model of the study is as follows:

$\mathrm{CASH}_{i, t}=\alpha+\delta_{0} \mathrm{SIZE}_{i, t}+\delta_{1} \mathrm{LEV}_{i, t}+\delta_{2} \mathrm{CE}_{i, t}+\delta_{3} \mathrm{GO}_{i, t}+\delta_{4} \mathrm{LIQ}_{i, t}+\delta_{5} \mathrm{CF}_{i, t}+\delta_{6} \mathrm{INT}_{i, t}+$

$\delta_{7} \mathrm{RISK}_{i, t}+\delta_{8} \mathrm{DIVD}+\delta_{9} \mathrm{STEX}_{i, t}+\lambda_{i}+\eta_{\mathrm{t}}+\varepsilon_{i, t}$

where $\lambda_{\mathrm{i}}$ and $\eta_{\mathrm{t}}$ are the industry and time dummy variables to capture industry and time specific effects; and $\varepsilon_{i, t}$ is the error term. The industry dummy factor takes on value of 1 for a specific sub-sector and 0 otherwise. Similarly, the time dummy factor takes on value of 1 for a specific year and 0 otherwise.

There are three main estimation methodologies for a panel dataset; the pooled OLS, the fixed effects and the random effects. The pooled OLS refers to the estimation of the simple OLS regression disregarding the cross-sectional and time dimensions of panel data. Therefore, pooled OLS is less consistent and efficient than fixed effects or random effects as it does not take into account the individual specific effects. In the fixed effects, the intercept may differ across individuals (companies) but each individual's intercept does not vary over time (i.e., it is time-invariant). Therefore, the dummy variable technique is used to allow the intercept to vary across individuals. The inclusion of the dummy variables in the fixed effects model results in loss of degrees of freedom. Instead, some relevant time-invariant explanatory 
variables having same value for all the cross-sectional units could have been included in the underlying fixed effects model.

This lack of knowledge about the true model is represented in the form of error term, which provides basis for random effects or error component model. In the random effects model, it is assumed that the sample individuals are drawn from large universe of population that have a common intercept and the differences in the intercept value of each individual is reflected in the error term (Gujarati and Porter, 2009, p. 602).

To select between fixed effects and pooled OLS methodologies, the F test is available in STATA econometric software. Moreover, the Breusch-Pagan Lagrange Multiplier (LM) test is used to select between random effects and pooled OLS methodologies. Apart from this, the Hausman test is used to select between one-way fixed effects and one-way random effects models. However, the typical one-way fixed effects estimation cannot be applied for the model in Equation (1) since the fixed effects estimation methodology does not accept the time-invariant variables such as the sub-sector dummy variables. The sub-sector dummy variables are central variables, and the sub-sectoral differences are the focus of the study. Moreover, the random effects do not provide estimations for the main variables of interests; and the characteristics of the sample and estimation model demand fixed effects.

The panel regression model in Equation (1) is a two-way fixed effects model by sub-sector and year as the model includes dummy variables of the two factors. "If some omitted variables are constant over time but vary across states, while others are constant across states but vary over time, then it is appropriate to include both state and time effects (Stock and Watson, 2003, p. 284). The two-way fixed effects model removes omitted variable bias emerging both from unobserved variables that is 
constant over time and across states (Stock and Watson, 2003, p. 284)." The F test result $[\mathrm{F}=22.05$ (p-value: 0.000$)]$ shows that all time and state dummy variables are jointly statistically significant. Moreover, STATA "testparm" command is run after fitting the least squares dummy variables to check for joint significance and its results are shown in Table 6 . The two-way fixed effects model is estimated by pooled OLS methodology. Therefore, the two-way fixed effects model is estimated and corrected for estimation problems such as heteroscedasticity and serial correlation. ${ }^{5}$

\subsubsection{Generalized method of moments (GMM)}

The difference GMM (Arellano and Bond, 1991) and the system GMM(Arellano and Bover, 1995; Blundell and Bond, 1998) are dynamic panel estimators used for panel data analyses. These two methods are developed to deal with various econometric issues such as: "large $\mathrm{N}$, small T", a linear functional relationship, heteroskedasticity, autocorrelation and fixed effects. The difference GMM methodolgy transforms all regressors, usually by differencing, and then uses the generalized method of moments (GMM). The system GMM methodology further develops the difference GMM methodology by making another assumption that first differences of instrument variables are uncorrelated with the fixed effects. This helps to increase the number of instrumental variables to increase the efficiency. As a result, a system of two equations is developed, which is called as system GMM.

Several empirical studies (Ozkan and Ozkan, 2004, García-Teruel and Martínez-Solano, 2008, Al-Najjar and Belghitar, 2011, Bigelli and Sánchez-Vidal, 2012 and Uyar and Kuzey, 2014) employed a dynamic model using the Generalized Method of Moments (GMM) technique. The dynamic model is employed as

\footnotetext{
${ }^{5}$ To select between the fixed effects and random effects models, unlike the one way error component model, the Hausman test does not hold for two-way error component model since there would be two "Between" estimators, one between cross sections and one between time periods (Kang, 1985; Baltagi, 2005, p. 73).
} 
according to Ozkan and Ozkan (2004), companies adjust to their target cash holdings. Companies need to determine the changes in the cash ratios that lead to partial adjustment and set a target level to undertake cash decisions. Hence, cash decisions made previously are utilized to explain cash levels achieved at any time (Ozkan and Ozkan, 2004). Moreover, GMM is popular for dealing with the problem of endogeneity. Endogeneity refers to the correlation of regressors with error term. The common causes of endogeneity include omitted variables, simultaneity and measurement errors. Furthermore, the Durbin-Wu Hausman test is used to detect the presence or absence of endogeneity. The F test result for Durbin-Wu Hausman test $[F=4.60$ (p-value: 0.000$)]$ shows the presence of endogeneity (i.e., the regressors are correlated with the error term).

GMM is used to overcome the endogeneity problem by employing instruments. The instruments are additional explanatory variables which are correlated with the other explanatory variables of the model, but are uncorrelated with the error term. Apart from this, the lagged dependent variable gives rise to autocorrelation. Furthermore, the time invariant features of companies might be correlated with the independent variables, which are also called as the fixed effects. Furthermore, the data set used in this study comprises of large $\mathrm{N}$ (i.e., number of companies) and small $\mathrm{T}$ (i.e., number of time periods), favoring the use of GMM methodology. Therefore, theoretically GMM is a superior econometric panel data methodology than two-way fixed effects as the former deals with all econometric problems mentioned above. In Equation 2, instruments of exogenous variables and lagged endogenous variables are used to control for correlation with error term. The dynamic panel data model of the study is as follows: 
$\mathrm{CASH}_{i, t}=\alpha+\delta_{0} \mathrm{CASH}_{i, t-1}+\delta_{1} \mathrm{SIZE}_{i, t}+\delta_{2} \mathrm{LEV}_{i, t}+\delta_{3} \mathrm{CE}_{i, t}+\delta_{4} \mathrm{GO}_{i, t}+\delta_{5} \mathrm{LIQ}_{i, t}+\delta_{6} \mathrm{CF}_{i, t}$

$+\delta_{7} \mathrm{INT}_{i, t}+\delta_{8} \mathrm{RISK}+\delta_{9} \mathrm{DIVD}_{i, t}+\delta_{10} \mathrm{STEX}_{i, t}+\lambda_{i}+\eta_{\mathrm{t}}+\varepsilon_{i, t}$

where $\lambda_{\mathrm{i}}$ and $\eta_{\mathrm{t}}$ are the industry and time dummy variables to capture sub-sector and time specific effects; and $\varepsilon_{i, t}$ is the error term. The industry dummy factor takes on value of 1 for a specific sub-sector and 0 otherwise. Similarly, the time dummy factor takes on value of 1 for a specific year and 0 otherwise. Moreover, $\delta_{0}$ is 1 minus the adjustment coefficient.

Following the assumption of 'white noise' disturbances, Arellano and Bover (1990) argue that if the errors are autocorrelated, then the GMM estimations make use of lagged variables as instruments. Therefore, the methodology used assumes that there is no second-order serial correlation in the errors in first differences. Hence, test proposed by Arellano and Bond (1991) is used to check for the absence of second-order serial correlation. Similarly, the Hansen (1982) test of overidentifying restrictions is used to check for the validity of instruments (i.e., absence of correlation between the instruments and the error term). In this study, 2-step GMM estimator is used to perform all estimations, since one-step estimations can lead to occurrence of heteroskedasticity. 


\section{Chapter 4}

\section{DATA DESCRIPTION}

This chapter provides details about sample panel data used in the study and explains the measurements of dependent as well as independent variables.

\subsection{Sampling}

Data are collected from the Thomson Reuters Datastream and WorldScope databases. The data are collected for the period between 2005 and 2016, since the Industry Classification Benchmark (ICB) in these two databases was introduced in 2005. Based on the ICB, 88 publicly traded companies are initially identified operating in the travel and leisure sector. These companies are traded on the MAINLSE, AIM-LSE and the ISDX.

Subsequently, the final set of panel data is prepared based on the following criteria. First, those years for companies with missing data for any parameter are discarded from the sample. Second, those companies of travel and leisure sector are selected having a minimum of two and five continuous time series observations for two-way fixed effects and generalized method of moments (GMM) methodologies respectively. Finally, the panel data are winsorized at the $1 \%$ level to avoid the potential estimation biases introduced by outlier observations. As a result, a total of 51 and 49 travel and leisure sector companies are obtained, generating a total of 476 and 411 observations for two-way fixed effects and generalized method of moments (GMM) methodologies between 2005 and 2016. The sample is comprehensive as 
travel and leisure sector companies of different size and market values are included and controlled for in the empirical analysis.

\subsection{Measurements}

\subsubsection{Dependent variable}

The study defines the dependent variable as the cash holdings, which include cash and cash equivalents containing cash on hand, short-term investments, petty cash, checks received but not yet deposited, and saving accounts. Cash holdings are assumed to be dependent on the determinants suggested by three theoretical models. Therefore, the determinants of cash holdings represent the independent variables of the study.

There are numerous definitions of cash holdings in the literature. First, Gill and Shah (2012) define the cash holdings as the ratio of cash and cash equivalents divided by total net assets and the net assets are found after deducting cash and cash equivalents. Second, Kim et al. (2011) and Pastor and Gama (2013) define it as the ratio of cash and marketable securities to total assets. Third, Drobetz and Grüninger (2007) and Lian et al. (2011) define the cash holdings as the ratio of cash and cash equivalents to total assets. Fourth, Steijvers and Niskanen (2013) define it to be total cash divided by total assets. Finally, Opler et al. (1999) describes it as the ratio of cash and marketable securities to total net assets.

This study defines cash holdings (CASH) as the ratio of cash and cash equivalents to total assets (e.g., Drobetz and Grüninger, 2007; Lian et al., 2011).

\subsubsection{Independent variables}

The determinants of cash holdings discussed in Chapter 2, are the independent variables employed in the study. This sub-section provides the measurement details for all the independent variables; size, leverage, capital 
expenditures, growth opportunities, liquidity, cash flow, asset intangibility, cash flow volatility, dividend payments dummy and stock exchange dummy.

Consistent with the empirical works of Bigelli and Sánchez-Vidal (2012), Lee and Powel (2011), and Uyar and Kuzey (2014), the natural logarithm of total assets (SIZE) is used as a proxy for the size effect. Leverage (LEV) is measured as by the ratio of total liabilities divided by total assets (e.g., Colquitt, Somer and Godwin, 1999; Kim et al., 2011). Capital expenditures (CE) is defined as the ratio of capital expenditures to total assets (e.g., Maheshwari and Rao, 2017; Uyar and Kuzey, 2014). To measure the growth opportunities (GO), the proxy is the market-to-book value ratio (e.g., Drobetz and Grüninger, 2007; Uyar and Kuzey, 2014). Liquidity (LIQ) is measured by the ratio of net working capital minus cash to total assets (e.g., Kim et al., 2013; Lian et al., 2011; Uyar and Kuzey, 2014). Moreover, net working capital is calculated as current assets minus current liabilities as suggested by Opler et al. (1999) and Ozkan and Ozkan (2004).

Cash flow (CF) is defined as the ratio of operating cash flows to total assets (e.g., Drobetz and Grüninger, 2007; Lee and Powell, 2011). The asset intangibility (INT) is defined as the ratio of intangible assets to total assets (e.g., Martinez-Sola et al., 2011). Cash flow volatility (RISK) is defined as the standard deviation of cash flow to total assets (e.g., Ozkan and Ozkan, 2004; Uyar and Kuzey, 2014). The dummy variable takes a value of one in the dividend payment years; otherwise, the dummy variable is zero in the non-dividend payment years (e.g., Kim et al., 2011; Kim et al., 2013). The dummy variable takes a value of one if a company is listed in the Main-LSE; otherwise, the dummy variable is zero for companies listed in AIMLSE and ISDX. 
In Table 1, the determinants of cash holdings, their abbreviations and definitions are summarized.

Table 1. Definitions of determinants and the respective abbreviations

\begin{tabular}{|c|c|c|}
\hline $\begin{array}{l}\text { Determinants as } \\
\text { Regressors }\end{array}$ & Abbreviations & Definition \\
\hline Size & SIZE & Ln (Total assets) \\
\hline Leverage & LEV & Total liabilities to total assets \\
\hline Capital expenditures & $\mathrm{CE}$ & Capital expenditures to total assets \\
\hline Growth Opportunities & GO & Market to book value \\
\hline Liquidity & LIQ & Networking capital minus cash to total assets \\
\hline Cash flow & $\mathrm{CF}$ & Operating cash flows to total assets \\
\hline Asset intangibility & INT & Intangible assets to total assets \\
\hline Cash flow volatility & RISK & Standard deviation of cash flow to total assets \\
\hline Dividend payment dummy & DIVD & Equals 1 if company pays dividend and 0 otherwise \\
\hline Stock Exchange dummy & STEX & $\begin{array}{l}\text { Equals } 1 \text { if company is listed in Main Market of } \\
\text { London Stock Exchange (Main-LSE) and } 0 \text { otherwise. }\end{array}$ \\
\hline
\end{tabular}




\section{Chapter 5}

\section{EMPIRICAL RESULTS}

This chapter provides univariate and multivariate analysis including descriptive statistics for sub-sectors of travel and leisure sector. Moreover, the chapter presents the descriptive statistics, correlation matrices and estimation results for regressand and regressors for both methodologies (i.e., two-way fixed effects and generalized method of moments (GMM)) separately.

\subsection{Descriptive statistics}

Table 2 shows the descriptive statistics for the cash holdings (CASH) for the sub-sectors and the travel and leisure sector over the sample period between 2005 and 2016. The table shows that the mean value of airlines is 0.2430 , the highest among the sub-sectors. The gambling sector has the second highest mean value of 0.1763. The lowest mean value for CASH belongs to the hotels sub-sector (0.0704), followed by the second lowest mean value of 0.0935 for the restaurants and bars subsector. Furthermore, the mean cash holdings ratio of travel and leisure sector as a whole is 0.1368 , showing that companies in the airlines, gambling and recreational services sub-sectors hold more cash on average than the ones in the whole sector. Similarly, companies in the rest of the sub-sectors, namely, hotels, restaurants and bars, and travel and tourism, hold less cash on average. 
Table 2. Descriptive statistics of cash holdings over 2005-2016: Travel and leisure sector, and its sub-sectors

\begin{tabular}{|c|c|c|c|c|c|c|c|c|c|c|c|c|c|}
\hline Sub-sectors & & 2005 & 2006 & 2007 & 2008 & 2009 & 2010 & 2011 & 2012 & 2013 & 2014 & 2015 & 2016 \\
\hline \multirow[t]{3}{*}{ Airlines } & Obs. & 3 & 3 & 3 & 3 & 3 & 3 & 4 & 5 & 4 & 4 & 4 & 4 \\
\hline & Mean & 0.3739 & 0.2874 & 0.1514 & 0.2469 & 0.2692 & 0.2433 & 0.2735 & 0.2241 & 0.2093 & 0.2801 & 0.3547 & 0.2721 \\
\hline & Median & 0.4317 & 0.3177 & 0.0633 & 0.3173 & 0.3178 & 0.2091 & 0.2634 & 0.2395 & 0.2084 & 0.2673 & 0.3486 & 0.2681 \\
\hline \multirow[t]{3}{*}{ Gambling } & Obs. & 7 & 8 & 8 & 8 & 8 & 8 & 10 & 10 & 10 & 10 & 9 & 8 \\
\hline & Mean & 0.0933 & 0.1991 & 0.1502 & 0.1091 & 0.1323 & 0.1146 & 0.1871 & 0.1784 & 0.2185 & 0.2428 & 0.2960 & 0.1952 \\
\hline & Median & 0.0641 & 0.0875 & 0.0889 & 0.1113 & 0.1022 & 0.0736 & 0.1429 & 0.1157 & 0.0943 & 0.1060 & 0.1230 & 0.1873 \\
\hline \multirow[t]{3}{*}{ Hotels } & Obs. & 3 & 3 & 4 & 4 & 4 & 4 & 4 & 5 & 5 & 5 & 5 & 5 \\
\hline & Mean & 0.0695 & 0.0611 & 0.0535 & 0.0593 & 0.0182 & 0.0281 & 0.0447 & 0.0580 & 0.0857 & 0.1322 & 0.1272 & 0.1084 \\
\hline & Median & 0.0470 & 0.0776 & 0.0511 & 0.0509 & 0.0101 & 0.0157 & 0.0380 & 0.0663 & 0.0516 & 0.0615 & 0.0592 & 0.0712 \\
\hline \multirow{3}{*}{$\begin{array}{l}\text { Recreational } \\
\text { Services }\end{array}$} & Obs. & 2 & 2 & 5 & 5 & 5 & 5 & 5 & 5 & 5 & 5 & 4 & 3 \\
\hline & Mean & 0.0305 & 0.0389 & 0.2218 & 0.1986 & 0.1981 & 0.1503 & 0.1440 & 0.1336 & 0.1757 & 0.1686 & 0.1799 & 0.1378 \\
\hline & Median & 0.0305 & 0.0389 & 0.0290 & 0.0374 & 0.0453 & 0.0286 & 0.0261 & 0.0730 & 0.1086 & 0.0695 & 0.0919 & 0.0232 \\
\hline \multirow{3}{*}{$\begin{array}{l}\text { Restaurants and } \\
\text { Bars }\end{array}$} & Obs. & 15 & 16 & 16 & 16 & 16 & 16 & 17 & 17 & 17 & 16 & 16 & 16 \\
\hline & Mean & 0.0464 & 0.1177 & 0.1002 & 0.0836 & 0.0754 & 0.0840 & 0.0759 & 0.1080 & 0.1114 & 0.1092 & 0.1086 & 0.1027 \\
\hline & Median & 0.0279 & 0.0317 & 0.0349 & 0.0289 & 0.0355 & 0.0272 & 0.0311 & 0.0338 & 0.0381 & 0.0572 & 0.0454 & 0.0462 \\
\hline \multirow{3}{*}{$\begin{array}{l}\text { Travel and } \\
\text { Tourism }\end{array}$} & Obs. & 5 & 5 & 7 & 7 & 7 & 7 & 7 & 7 & 7 & 7 & 6 & 6 \\
\hline & Mean & 0.1017 & 0.0928 & 0.1540 & 0.1166 & 0.1107 & 0.1237 & 0.1172 & 0.1039 & 0.1302 & 0.1304 & 0.1638 & 0.1783 \\
\hline & Median & 0.0867 & 0.0901 & 0.1456 & 0.1529 & 0.1030 & 0.0660 & 0.0865 & 0.1030 & 0.1451 & 0.1345 & 0.1316 & 0.1343 \\
\hline \multirow{3}{*}{$\begin{array}{l}\text { Travel and Leisure } \\
\text { Sector }\end{array}$} & Obs. & 35 & 37 & 43 & 43 & 43 & 43 & 47 & 49 & 48 & 47 & 44 & 42 \\
\hline & Mean & 0.1192 & 0.1328 & 0.1385 & 0.1356 & 0.1339 & 0.1240 & 0.1404 & 0.1343 & 0.1551 & 0.1772 & 0.1721 & 0.1509 \\
\hline & Median & 0.1146 & 0.1072 & 0.0688 & 0.1164 & 0.1023 & 0.0700 & 0.0980 & 0.1052 & 0.1076 & 0.1160 & 0.0772 & 0.0869 \\
\hline
\end{tabular}

Note: The descriptive statistics is based on unwinsorized data. 


\subsection{Two-way fixed effects estimation}

\subsubsection{Descriptive statistics}

Table 3 shows the descriptive statistics for the regressand and the regressors. The number of observations for each variable is 476 . In the table, cash holdings (CASH) of the travel and leisure companies has a mean value of 0.1330 . The mean value for firm size (SIZE) of travel and leisure companies is 12.9768 , with a standard deviation of 2.2096, showing a significant variance in size across companies. The mean value of leverage (LEV) is 0.5762 , indicating that on average, travel and leisure companies use debt financing more than equity financing. Capital expenditures (CE) has a mean value of 0.0621 . The mean value of growth opportunities (GO) is 3.3491, showing that the market value of travel and leisure companies is three times of their book value on average. Liquidity (LIQ) has a mean value of -0.1219 , indicating that on average, companies in travel and leisure sector typically have liquidity constraints. The mean value of cash flow $(\mathrm{CF})$ is 0.0857 . The mean value of (INT) is 0.2151 , showing that on average, companies in travel and leisure sector invest $21 \%$ of total assets in tangible assets. The mean value of risk (RISK) is 0.0670 , indicating that approximately $6 \%$ of the travel and leisure companies have volatile cash flows. The mean value of DIVD is 0.6994, showing that approximately $70 \%$ of the travel and leisure companies pay dividends during the sample period. Lastly, the mean value of STEX is 0.6622, indicating that approximately $66 \%$ of travel and leisure companies are listed on the Main-LSE during the sample period. 
Table 3. Descriptive statistics (Two-way fixed effects)

\begin{tabular}{cccccc}
\hline & Mean & Median & SD & Min & Max \\
\hline CASH & 0.1330 & 0.0712 & 0.1509 & 0.0010 & 0.6376 \\
SIZE & 12.9768 & 13.3353 & 2.2096 & 8.2728 & 17.0131 \\
LEV & 0.5762 & 0.5888 & 0.2420 & 0.0674 & 1.2636 \\
CE & 0.0621 & 0.0402 & 0.0650 & 0.0004 & 0.3289 \\
GO & 3.3491 & 1.835 & 5.3933 & -5.7600 & 34.3700 \\
LIQ & -0.1219 & -0.1166 & 0.1748 & -0.6270 & 0.6792 \\
CF & 0.0857 & 0.0804 & 0.1224 & -0.4530 & 0.4434 \\
INT & 0.2151 & 0.0963 & 0.2481 & 0.0000 & 0.9166 \\
RISK & 0.0670 & 0.0297 & 0.0987 & 0.0018 & 0.4906 \\
DIVD & 0.6994 & 1.0000 & 0.4589 & 0.0000 & 1.0000 \\
STEX & 0.6622 & 1.0000 & 0.4733 & 0.0000 & 1.0000 \\
\hline
\end{tabular}

Notes: The regressand and regressors in the table are defined in Table 1.

\subsubsection{Correlation matrix}

Table 4 shows the correlations among the variables. The correlation between any two regressors is less than 0.50 . Thus, multicollinearity is unlikely to be a problem in the estimations. The table shows that CE, GO, CF and RISK are positively correlated with $\mathrm{CASH}$ and the correlations are statistically significant. CASH is negatively correlated with SIZE, LEV and INT and the correlations are statistically significant. However, LIQ has statistically insignificant correlation with CASH. Based on the univariate analysis, the correlations signs for SIZE, LEV GO, CF, INT and RISK are in line with the hypothesized relationships, but this is not the case for CE. Further multivariate analysis is needed and is carried out in the following sections. 
Table 4. Pearson correlation matrix (Two-way fixed effects)

\begin{tabular}{|c|c|c|c|c|c|c|c|c|c|}
\hline & $\mathrm{CASH}$ & SIZE & LEV & $\mathrm{CE}$ & GO & LIQ & $\mathrm{CF}$ & INT & RISK \\
\hline$\overline{\mathrm{CASH}}$ & 1 & & & & & & & & \\
\hline SIZE & $-0.333^{*}$ & 1 & & & & & & & \\
\hline LEV & $-0.165^{*}$ & $0.471^{*}$ & 1 & & & & & & \\
\hline $\mathrm{CE}$ & $0.115^{*}$ & $-0.248 *$ & $-0.146^{*}$ & 1 & & & & & \\
\hline GO & $0.177 *$ & -0.009 & $0.191 *$ & 0.043 & 1 & & & & \\
\hline LIQ & -0.045 & $-0.192 *$ & $-0.487 *$ & $-0.159 *$ & $-0.118^{*}$ & 1 & & & \\
\hline $\mathrm{CF}$ & $0.082 * * *$ & $0.171^{*}$ & 0.042 & 0.070 & $0.283^{*}$ & $-0.184 *$ & 1 & & \\
\hline INT & $-0.109 *$ & $0.184^{*}$ & 0.048 & $-0.363 *$ & -0.066 & $0.118^{*}$ & 0.048 & 1 & \\
\hline RISK & $0.276^{*}$ & $-0.426^{*}$ & $-0.111 *$ & -0.042 & 0.042 & $-0.111 * *$ & $-0.173 *$ & $0.088 * *$ & 1 \\
\hline
\end{tabular}

Notes: $* * *, * *$ and $*$ are statistically significant at $10 \%, 5 \%$ and $1 \%$ respectively.

\subsubsection{Estimation results}

Table 5 shows the estimation results for two variations of Equation (1). The first variation (Model 1) does not include the sub-sector and year dummy variables, the second variation (Model 2) includes both sub-sector and year dummy variables. For both models, the F-statistics show that regressors are jointly statistically significant as the determinants of cash holdings.

In both models, SIZE, LEV, GO, CF, INT, RISK, DIVD and STEX are statistically significant and have consistent signs with the hypotheses. In Model (1), LIQ is statistically significant at conventional levels, while it is statistically insignificant in Model (2). It can be safely assumed that LIQ is statistically significant. The signs of SIZE, LEV, LIQ, INT and DIVD show negative effects on cash holdings. The positive coefficients of GO, CF, RISK and STEX suggest that cash holdings are positively affected by growth opportunities, cash flows, cash flow volatility and stock exchange. Table 5 also shows that $\mathrm{CE}$ is not statistically significant at conventional levels. 
Focusing on the sub-sectoral differences, the travel and tourism sub-sector is dropped to avoid the dummy trap problem and is the reference sub-sector. In both models, the statistically significant positive coefficient of the airlines sub-sector shows that airlines companies hold more cash than travel and tourism companies, while the statistically significant negative coefficients of hotels, and restaurants and bars companies show that these sub-sectors hold less cash than travel and tourism companies. The recreational services sub-sector coefficient is not statistically significant, indicating that the cash holdings of the companies operating in this subsector are indifferent from the ones in the travel and tourism sub-sector.

Focusing on the year specific effects in Model (2), the 2005-year dummy variable is also dropped to avoid the dummy trap problem, and 2005 is the reference year. The statistically significant positive coefficients of 2014, 2015 and 2016 show that travel and leisure companies hold more cash in these three years than 2005.The p-values for the years 2006, 2007, 2008, 2009, 2010, 2011, 2012 and 2013 are not statistically significant at the conventional levels. 
Table 5. Estimation results (Two-way fixed effects)

\begin{tabular}{|c|c|c|c|c|c|}
\hline Regressors & Expected sign & Model (1) & $\mathrm{p}$-value & Model (2) & $\mathrm{p}$-value \\
\hline SIZE & Positive/Negative & $-0.0194^{*}$ & 0.000 & $-0.0191^{*}$ & 0.001 \\
\hline LEV & Negative & $-0.0936^{* *}$ & 0.011 & $-0.1179^{*}$ & 0.003 \\
\hline $\mathrm{CE}$ & Negative & -0.0340 & 0.803 & -0.1449 & 0.305 \\
\hline GO & Positive/Negative & $0.0042^{*}$ & 0.001 & $0.0043^{*}$ & 0.000 \\
\hline LIQ & Negative & $-0.1237^{* *}$ & 0.011 & -0.0579 & 0.215 \\
\hline $\mathrm{CF}$ & Positive & $0.0846^{* *}$ & 0.046 & $0.0755^{* *}$ & 0.027 \\
\hline INT & Positive/Negative & $-0.0731^{*}$ & 0.003 & $-0.1871^{*}$ & 0.000 \\
\hline RISK & Positive/Negative & $0.2624^{* *}$ & 0.011 & $0.2114^{* *}$ & 0.029 \\
\hline DIVD & Negative & $-0.0406^{* *}$ & 0.014 & $-0.0255^{* * *}$ & 0.091 \\
\hline STEX & Positive/Negative & $0.0532^{* *}$ & 0.030 & $0.0655^{*}$ & 0.003 \\
\hline Airlines & - & - & - & $0.0734^{*}$ & 0.008 \\
\hline Gambling & - & - & - & 0.0055 & 0.830 \\
\hline Hotels & - & - & - & $-0.1287^{*}$ & 0.000 \\
\hline $\begin{array}{l}\text { Recreational } \\
\text { Services }\end{array}$ & - & - & - & 0.0310 & 0.214 \\
\hline $\begin{array}{l}\text { Restaurants and } \\
\text { Bars }\end{array}$ & - & - & - & $-0.1074^{*}$ & 0.000 \\
\hline 2006 & - & - & - & 0.0183 & 0.458 \\
\hline 2007 & - & - & - & 0.0085 & 0.740 \\
\hline 2008 & - & - & - & -0.0295 & 0.252 \\
\hline 2009 & - & - & - & -0.0221 & 0.378 \\
\hline 2010 & - & - & - & -0.0199 & 0.381 \\
\hline 2011 & - & - & - & 0.0016 & 0.943 \\
\hline 2012 & - & - & - & 0.0097 & 0.637 \\
\hline 2013 & - & - & - & 0.0337 & 0.168 \\
\hline 2014 & - & - & - & $0.0511^{* * *}$ & 0.059 \\
\hline 2015 & - & - & - & $0.0526^{* *}$ & 0.043 \\
\hline 2016 & - & - & - & $0.0525^{* *}$ & 0.032 \\
\hline Constant & - & $0.3939^{*}$ & 0.000 & $0.4633^{*}$ & 0.000 \\
\hline Observations & - & 476 & - & 476 & - \\
\hline Adj. $R^{2}$ & - & 0.2004 & - & 0.3755 & - \\
\hline F-stat & - & $10.04^{*}$ & 0.000 & $8.92^{*}$ & 0.000 \\
\hline
\end{tabular}

Notes: The dependent variable CASH is scaled as cash and cash equivalent to total assets; SIZE is measured by natural logarithm of total assets; LEV is measured by total liabilities to total assets; $\mathrm{CE}$ is measured by capital expenditures to total assets; GO is measured by market to book value; LIQ is scaled by net working capital minus cash to total assets; CF is scaled by operating cash flows to total assets; INT is scaled by intangible assets to total assets; RISK is scaled by standard deviation of cash flow to total assets; DIVD is a dummy variable; and it equals to 1 if company pays dividend and 0 otherwise. STEX is a dummy variable; and it equals to 1 if company is listed on Main-LSE and 0 otherwise. $* * *, * *$ and $*$ are statistically significant at $10 \%, 5 \%$ and $1 \%$ respectively. 
Table 6 shows the impact of sub-sectors on the cash holdings of the travel and leisure sector. It also shows the impact of sample time period and the sub-period time effects before, during and after the global financial crisis on cash holdings of the travel and leisure sector ${ }^{6}$. As shown in Panel A, in both models (i.e., Model 1 and 2 of Table 5), the $\mathrm{Chi}^{2}$ value shows that the travel and leisure sub-sectors are jointly statistically significant and determine the cash holdings.

In Panel B, using the estimation results of Model 2, the $\mathrm{Chi}^{2}$ value shows that the sample years are jointly statistically significant. Further examination is carried out and the $\mathrm{Chi}^{2}$ results for selected sub-periods are shown in the second column of Panel B. Relative to the reference year 2005, the sub-period time impact on cash holdings during the pre-crisis period (i.e., 2006 and 2007) and during the crisis period (i.e., 2008 and 2009) are jointly statistically insignificant respectively. In other words, there are no statistically significant changes in cash holdings during these two periods relative to the level in the reference year 2005. However, the post-crisis subperiod time impact on cash holdings (i.e., 2010, 2011, 2012, 2013, 2014, 2015 and 2016) is jointly statistically significant. Particularly, the positive coefficients in years 2014, 2015 and 2016 are statistically significant (see Table 5).

\footnotetext{
${ }^{6}$ In STATA, the "testparm" command is used. It reports the $\mathrm{Chi}^{2}$-statistic and is a post-estimation test for testing the joint statistical significance of selected regressors.
} 
Table 6. Sub-Sector, sample time period and sub-period effects.

\begin{tabular}{ll} 
& Panel A. Sub-sectors \\
\hline Model (1): Sub-sectors & Model (2): Sub-sectors \\
\hline Airlines $=0$ & Airlines $=0$ \\
Gambling $=0$ & Hotels $=0$ \\
Hotels $=0$ & Recreational Services $=0$ \\
Recreational Services $=0$ & Restaurants and Bars $=0$ \\
Restaurants and Bars $=0$ & \\
& \\
Chi $^{2}(\mathrm{p}$-value $)=11.96^{* *}(0.0353)$ & Chi $^{2}(\mathrm{p}$-value $)=12.87^{* *}(0.0246)$ \\
\hline
\end{tabular}

Panel B. Time periods

\begin{tabular}{|c|c|}
\hline Model (2): Sample time period & Model (2): Selected sub-periods \\
\hline Sample period & Pre-crisis sub-period \\
\hline $2006=0$ & $2006=0$ \\
\hline $2007=0$ & $2007=0$ \\
\hline $2008=0$ & $\mathrm{Chi}^{2}(\mathrm{p}$-value $)=3.48(0.175)$ \\
\hline \multicolumn{2}{|l|}{$2009=0$} \\
\hline $2010=0$ & $\underline{\text { Crisis Period }}$ \\
\hline $2011=0$ & $2008=0$ \\
\hline $2012=0$ & $2009=0$ \\
\hline $2013=0$ & $\mathrm{Chi}^{2}(\mathrm{p}$-value $)=0.31(0.857)$ \\
\hline \multicolumn{2}{|l|}{$2014=0$} \\
\hline \multicolumn{2}{|l|}{$2015=0$} \\
\hline $2016=0$ & $\underline{\text { Post-Crisis Period }}$ \\
\hline & $2010=0$ \\
\hline & $2011=0$ \\
\hline & $2012=0$ \\
\hline & $2013=0$ \\
\hline & $2014=0$ \\
\hline & $2015=0$ \\
\hline & $2016=0$ \\
\hline $\mathrm{Chi}^{2}(\mathrm{p}$-value $)=15.23^{* * * *}(0.0846)$ & $\mathrm{Chi}^{2}(\mathrm{p}$-value $)=10.25^{* * *}(0.0685)$ \\
\hline
\end{tabular}

Note: $* * *$ statistically significant at $10 \%$ level, $* *$ statistically significant at $5 \%$ level; *statistically significant at $1 \%$ level. 


\subsection{Generalized method of moments (GMM) estimation}

\subsubsection{Descriptive statistics}

Table 7 shows the descriptive statistics for the regressand and the regressors. The number of observations for each variable is 411 . In the table, cash holdings (CASH) has a mean value of 0.1331 . The mean value for firm size (SIZE) of travel and leisure companies is 12.9875 , with a standard deviation of 2.2083 , showing a significant variance in size across companies. The mean value of leverage (LEV) is 0.5779 , indicating that on average, travel and leisure companies use debt financing more than equity financing. Capital expenditures (CE) has a mean value of 0.0627 . The mean value of growth opportunities $(\mathrm{GO})$ is 3.3593, showing that the market value of travel and leisure companies is three times of their book value on average. Liquidity (LIQ) has a mean value of -0.1232 , indicating that on average, companies in travel and leisure sector typically have liquidity constraints. The mean value of cash flow (CF) is 0.0881 . The mean value of (INT) is 0.2120 , showing that on average, companies in travel and leisure sector invest $21 \%$ of total assets in tangible assets. The mean value of risk (RISK) is 0.0660 , indicating that approximately $6 \%$ of the travel and leisure companies have volatile cash flows. The mean value of DIVD is 0.7044 , showing that approximately $70 \%$ of the travel and leisure companies pay dividends during the sample period. Lastly, the mean value of STEX is 0.6724, indicating that approximately $67 \%$ of travel and leisure companies are listed on the Main-LSE during the sample period. 
Table 7. Descriptive statistics (GMM)

\begin{tabular}{|c|c|c|c|c|c|}
\hline & Mean & Median & SD & Min & Max \\
\hline CASH & 0.1331 & 0.0712 & 0.1514 & 0.0010 & 0.6376 \\
\hline SIZE & 12.9875 & 13.3353 & 2.2083 & 8.2728 & 17.0131 \\
\hline LEV & 0.5779 & 0.5894 & 0.2424 & 0.0674 & 1.2636 \\
\hline $\mathrm{CE}$ & 0.0627 & 0.0409 & 0.0652 & 0.0004 & 0.3289 \\
\hline GO & 3.3593 & 1.835 & 5.4259 & -5.7600 & 34.3700 \\
\hline LIQ & -0.1232 & -0.1184 & 0.1748 & -0.6270 & 0.6792 \\
\hline $\mathrm{CF}$ & 0.0881 & 0.0816 & 0.1203 & -0.4530 & 0.4434 \\
\hline INT & 0.2120 & 0.0939 & 0.2460 & 0.0000 & 0.9166 \\
\hline RISK & 0.0660 & 0.0297 & 0.1057 & 0.0018 & 0.4906 \\
\hline DIVD & 0.7044 & 1.0000 & 0.4567 & 0.0000 & 1.0000 \\
\hline STEX & 0.6724 & 1.0000 & 0.4697 & 0.0000 & 1.0000 \\
\hline
\end{tabular}

Notes: The regressand and regressors in the table are defined in Table 1.

\subsubsection{Correlation matrix}

Table 8 shows the correlations among the variables. The correlation between any two regressors is less than 0.50 . Thus, multicollinearity is unlikely to be a problem in the estimations. The table shows that $\mathrm{CE}, \mathrm{GO}, \mathrm{CF}$ and RISK are positively correlated with $\mathrm{CASH}$ and the correlations are statistically significant. CASH is negatively correlated with SIZE, LEV and INT and the correlations are statistically significant. However, LIQ has statistically insignificant correlation with CASH. Based on the univariate analysis, the correlations signs for SIZE, LEV GO, CF, INT and RISK are in line with the hypothesized relationships, but this is not the case for CE. Further multivariate analysis is needed and is carried out in the following sections. 
Table 8. Pearson correlation matrix (GMM)

\begin{tabular}{llllllllll}
\hline & CASH & SIZE & LEV & CE & GO & LIQ & CF & INT & RISK \\
\hline CASH & 1 & & & & & & & & \\
SIZE & $-0.331^{*}$ & 1 & & & & & & \\
LEV & $-0.160^{*}$ & $0.464^{*}$ & 1 & & & & & \\
CE & $0.117^{*}$ & $-0.258^{*}$ & $-0.155^{*}$ & 1 & & & & \\
GO & $0.174^{*}$ & -0.006 & $0.195^{*}$ & $0.043^{*}$ & 1 & & & \\
LIQ & -0.055 & $-0.187^{*}$ & $-0.484^{*}$ & $-0.154^{*}$ & $-0.124^{*}$ & 1 & & \\
CF & $0.095^{* *}$ & $0.156^{*}$ & 0.023 & $0.056^{*}$ & $0.293^{*}$ & $-0.171^{*}$ & 1 & & \\
INT & $-0.113^{*}$ & $0.209^{*}$ & 0.066 & $-0.358^{*}$ & 0.042 & $-0.127^{* *}$ & $0.079^{* * *}$ & 1 & \\
RISK & $0.254^{*}$ & $-0.388^{*}$ & -0.022 & -0.029 & -0.067 & $-0.178^{*}$ & $-0.162^{*}$ & 0.018 & 1 \\
\hline
\end{tabular}

Notes: $* * *, * *$ and $*$ are statistically significant at $10 \%, 5 \%$ and $1 \%$ respectively.

\subsubsection{Estimation results}

Table 9 shows the estimation results for two variations of equation (2), following 2-stage GMM estimator. The first variation (Model 1) includes year dummy variables, but does not include the sub-sector dummy variables. However, the second variation (Model 2) includes both sub-sector and year dummy variables.

The lagged dependent variable $\mathrm{CASH}_{\mathrm{t}-1}$ is significant and positive, showing the dynamic nature of the model employed, followed by cash holding decisions. The result also shows that companies attempts to balance the costs and benefits of holding cash and follow a target cash levels. In both models, SIZE, LEV, CE, LIQ, GO, CF and DIVD are statistically significant and have consistent signs with the hypotheses. In Model (1), RISK is statistically insignificant at conventional levels, while it is statistically significant in Model (2). Similarly, in Model (1), STEX is statistically significant at conventional levels, while it is statistically insignificant in Model (2). The signs of LEV, CE, LIQ, RISK, DIVD and STEX show negative effects on cash holdings. The positive coefficients of SIZE, GO and CF suggest that cash holdings are positively affected by size, growth opportunities and cash flows. Table 9 also shows that INT is not statistically significant at conventional levels. 
Focusing on the sub-sectoral differences, the travel and tourism sub-sector is dropped to avoid the dummy trap problem and is the reference sub-sector. In model (2), the statistically significant positive coefficient of the airlines sub-sector shows that airlines companies hold more cash than travel and tourism companies. The gambling, restaurants and bars and recreational services sub-sectors coefficients are not statistically significant, indicating that the cash holdings of the companies operating in these sub-sectors are indifferent from the ones in the travel and tourism sub-sector.

Table 9 also shows the presence of negative first-order serial correlation $(\operatorname{AR}(1))$, while the second-order serial correlation $(\operatorname{AR}(2))$ shows that no secondorder serial correlation has been detected during estimations. Moreover, the Hansen test results for both the models show that null hypothesis of valid instruments cannot be rejected, which confirms that the instruments are valid and there is no correlation between instruments and error term. 
Table 9. Estimation results (GMM)

\begin{tabular}{|c|c|c|c|c|c|}
\hline Regressors & Expected sign & Model (1) & $\mathrm{p}$-value & Model (2) & p-value \\
\hline $\mathrm{CASH}_{\mathrm{t}-1}$ & Positive & $0.8765^{*}$ & 0.000 & $0.8838^{*}$ & 0.000 \\
\hline SIZE & Positive/Negative & $0.0097^{* * * *}$ & 0.078 & $0.0156^{*}$ & 0.024 \\
\hline LEV & Negative & $-0.0858^{*}$ & 0.000 & $-0.1016^{*}$ & 0.022 \\
\hline $\mathrm{CE}$ & Negative & $-0.1102^{* * *}$ & 0.078 & $-0.2185^{*}$ & 0.013 \\
\hline GO & Positive/Negative & $0.0050^{*}$ & 0.001 & $0.0083^{*}$ & 0.000 \\
\hline LIQ & Negative & $-0.0983^{*}$ & 0.000 & $-0.0909^{*}$ & 0.023 \\
\hline $\mathrm{CF}$ & Positive & $0.2056^{*}$ & 0.000 & $0.1832^{*}$ & 0.001 \\
\hline INT & Positive/Negative & 0.0167 & 0.296 & 0.0220 & 0.756 \\
\hline RISK & Positive/Negative & 0.0039 & 0.939 & $-0.1418^{* * * *}$ & 0.085 \\
\hline DIVD & Negative & $-0.0837^{*}$ & 0.000 & $-0.0826^{*}$ & 0.002 \\
\hline STEX & Positive/Negative & $-0.0297^{* * *}$ & 0.063 & -0.0523 & 0.231 \\
\hline Airlines & - & - & - & $0.1656^{*}$ & 0.025 \\
\hline Gambling & - & - & - & 0.0521 & 0.256 \\
\hline Hotels & - & - & - & -0.0038 & 0.941 \\
\hline $\begin{array}{l}\text { Recreational } \\
\text { Services }\end{array}$ & - & - & - & 0.0171 & 0.650 \\
\hline $\begin{array}{l}\text { Restaurants and } \\
\text { Bars }\end{array}$ & - & - & - & 0.0384 & 0.363 \\
\hline Year dummies & - & Yes & - & Yes & - \\
\hline Constant & - & 0.5077 & 0.213 & 0.0031 & 0.996 \\
\hline Observations & - & 411 & - & 411 & - \\
\hline $\mathrm{AR}(1)$ & - & $-1.76^{* * *}$ & - & $-2.24^{*}$ & - \\
\hline $\operatorname{AR}(2)$ & - & 0.28 & - & -1.49 & - \\
\hline Hansen & & 15.74 & & 23.09 & \\
\hline
\end{tabular}

Notes: The dependent variable CASH is scaled as cash and cash equivalent to total assets; SIZE is measured by natural logarithm of total assets; LEV is measured by total liabilities to total assets; $\mathrm{CE}$ is measured by capital expenditures to total assets; GO is measured by market to book value; LIQ is scaled by net working capital minus cash to total assets; CF is scaled by operating cash flows to total assets; INT is scaled by intangible assets to total assets; RISK is scaled by standard deviation of cash flow to total assets; DIVD is a dummy variable; and it equals to 1 if company pays dividend and 0 otherwise. STEX is a dummy variable; and it equals to 1 if company is listed on Main-LSE and 0 otherwise. Correlations 1 and 2 are distributed as standard normal $\mathrm{N}(0,1)$ under the null hypothesis of no serial correlation for firstand second-order autocorrelations. Hansen test is for over-identifying restrictions, distributed as chi-square under the null hypothesis of instrument validity. ***,** and $*$ are statistically significant at $10 \%, 5 \%$ and $1 \%$ respectively. 


\subsection{Argumentative explanations and comparative analysis}

In this section, the focus is on the statistically significant determinants. This section also presents the comparative analysis of empirical results for both estimation methodologies i.e. two-way fixed effects and generalized method of moments (GMM).

\subsubsection{Size}

In Table 9, following the estimation results of GMM methodology, the positive coefficient of SIZE validates $\mathrm{H} 1$ and supports the pecking-order model. Ferreira and Vilela (2004) argue that larger companies are presumed to be more successful and need to hold more cash even after making investment. Furthermore, larger companies are more diversified and managers of these companies are more flexible in devising the financial policies and tend to hold more cash. The positive coefficient also supports the free cash flow model. Larger companies typically have a widely dispersed ownership structure resulting in weaker monitoring and higher agency problems. In large companies, managers have more discretionary managerial power and hence, tend to hold excessive cash (Ferreira and Vilela, 2004).

However, in Table 5, following the estimation results of two- way fixed effects methodology, the negative coefficient of SIZE also validates H1 and supports the transaction motive of trade-off theory, but contradicts the pecking-order and cash flow models. Consistent with the precautionary motive of trade-off theory, small companies tend to keep more cash. Similarly, it is in accordance with the argument of Ozkan and Ozkan (2004) that small companies tend to amass cash to cope with situations of financial distress. Bigger companies operating in the UK travel and leisure sector hold less cash since they are expected to have less financial distress, easier access to capital markets, and less information asymmetry. 


\subsubsection{Leverage}

Table 9 shows a negative link of leverage (LEV) with cash holdings and validates $\mathrm{H} 2$. The result supports all the three theoretical models. Supporting the trade-off model, the result shows that travel and leisure companies with more leverage hold less cash due to being closely monitored, and can use the debt financing as a substitute mechanism for holding less cash (Al-Najjar and Belghitar, 2011; D’Mello et al., 2008; Ferreira and Vilela, 2004; Maheshwari and Rao, 2017). This finding does not support the argument of Islam (2012) that leveraged companies keep more cash to reduce the financial distress costs. The result also supports the pecking-order model. Following the financing hierarchy of the pecking-order model, as the degree of investment exceeds the amount of retained earnings, the level of cash holdings decreases with an increase in the amount of debt (Ferreira and Vilela, 2004).

The results also supports the free cash flow model, since higher leverage act as an effective monitoring mechanism, rendering less discretionary powers to managers over the use of funds. As discussed in the hypotheses section, considering the characteristics of travel and leisure sector, leverage is used as substitute cash financing. Moreover, in Table 5, following estimation results of two-way fixed effects methodology, there is also a negative relationship between leverage and cash holdings of travel and leisure sector.

\subsubsection{Capital expenditures}

Following the estimations results of generalized method of moments (GMM) methodology, the negative effect of capital expenditures (CE) on cash holdings validates $\mathrm{H} 3$ and shows that travel and leisure companies in travel and leisure sector hold less cash as capital expenditures can lead to higher profitability and easier and 
cheaper access to debt financing (Maheshwari and Rao, 2017). Contrary to the findings of Opler et al (1999), the result supports the findings of Kim et al (2011), Kim et al (2013) and Bates et al (2009), who argue that capital expenditures enable companies to acquire tangible assets, and such assets can be pledged as collateral for borrowing, which mitigates the need for holding cash reserves. Therefore, travel and leisure companies with greater capital expenditures have weak precautionary motive due to their easier access to debt markets. However, in Table 5, following the estimation results of two-way fixed effects methodology, capital expenditures (CE) explanatory variable is statistically insignificant.

\subsubsection{Growth opportunities}

In Table 9, the positive effect of growth opportunities (GO) on cash holdings validates $\mathrm{H} 4$ and supports the pecking-order model as companies need cash to curtail the adverse selection costs of external financing. This result also supports the argument that firms need to keep more cash to save on opportunity costs in tapping new profitable projects (Uyar and Kuzey, 2014). Similarly, companies need to amass more cash to fund future profitable projects and avoid higher costs of external financing (Garcia-Teruel and Martinez-Solano, 2008). Moreover, the result supports the precautionary motive of trade-off theory companies with more growth opportunities hold cash to avoid liquidity shortages (Hardin et al., 2009).

The free cash flow model predicts a negative coefficient for GO and the sign result is inconsistent with this model. Ferreira and Vilela (2004) argue that entrenched managers in companies with poor growth opportunities tend to stockpile cash and invest in unprofitable projects. However, the personal interests of managing

a bigger company and having higher compensations destroy company value. Therefore, the free cash flow model predicts a negative relationship. Similarly, in 
Table 5, following estimation results of two-way fixed effects methodology, there is also a positive relationship between capital expenditures and cash holdings of travel and leisure sector.

\subsubsection{Liquidity}

In Table 9, the negative effect of liquidity (LIQ) on cash holdings validates H5 and supports the prediction of trade-off model. This result supports the argument that companies having more liquidity or liquid asset substitutes hold less cash (Uyar and Kuzey, 2014). Furthermore, the negative liquidity effect on cash holdings also supports the findings of previous empirical works (Kim et al., 2013; Lian et al., 2011). In Table 3, the negative mean and median values for LIQ indicate cash squeeze rather than having free cash flow in this sector. Similarly, in Table 5, following estimation results of two-way fixed effects methodology, there is also a negative relationship between liquidity and cash holdings of travel and leisure sector.

\subsubsection{Cash flow}

In Table 9, the positive effect of cash flows (CF) on cash holdings validates H6. The positive impact supports the argument of Lian et al. (2011) that companies with higher cash flows are capable of more cash savings. The result supports the precautionary and transaction motive of trade-off theory as companies with high cash flows tend to hold more cash, not only to take advantage of prospective growth opportunities but also to alleviate the risk in future uncertainties (Opler et al., 1999). Similarly, the result also supports the pecking-order theory as companies with more information asymmetries tend to retain cash flows to avoid costly external funds for financing future investments. However, the positive coefficient does not support the free cash flow model. Similarly, in Table 5, following estimation results of two-way 
fixed effects methodology, there is also a positive relationship between cash flows and cash holdings of travel and leisure sector.

\subsubsection{Asset intangibility}

In Table 9, following the estimation results of GMM methodology, asset intangibility (INT) explanatory variable is statistically insignificant. However, in Table 6, following the estimation methodology of two-way fixed effects, INT exerts a negative and significant impact on cash holdings and validates $\mathrm{H} 7$. The result contradicts the precautionary motive of trade-off theory. Companies are investing more in intangibles assets to achieve uniqueness and to improve their competitive advantage (Lev, 2000; Nakamura, 2001). The travel and leisure sector has witnessed numerous information technology progresses over the past decades (Ip et al., 2011) and is more technology-intensive (Gursoy and Swanger, 2007). Therefore, travel and leisure companies are more dependent on intangible assets and have become more technology-, service- and internet-oriented. Hence, companies operating in travel and leisure sector can gain competitive advantage to become more profitable due to the effective implementation of information and communication technologies and tend to hold less cash.

\subsubsection{Cash flow volatility}

In Table 9, the negative effect of cash flow volatility (RISK) on cash holdings validates H8. The negative coefficient supports the argument that increased cost of capital and agency costs are related with high cash flow volatility (Ferreira and Vilela, 2004). Companies which are characterized by high cost of capital could not hold cash because the cost of holding cash is higher than the cash flows generated by that cash (Ferreira and Vilela, 2004). Hence, it is very costly for the companies with high cost of capital to hold cash for precautionary motives. However, in Table 
5, following the estimation results of two- way fixed effects methodology, the positive coefficient of RISK also validates $\mathrm{H} 8$ and supports the precautionary motive of trade-off theory. The result supports the argument that companies with more variability in cash flows are highly exposed to cash shortages (Ozkan and Ozkan, 2004) and need to hold more cash.

\subsubsection{Dividend payment}

In Table 9, the negative coefficient of dividend dummy (DIVD) confirms H9. Supporting the empirical finding of Kim et al. (2011) for the US restaurants and bars sub-sector, dividend payment negatively affects the cash holdings. The result is also consistent with the notion of Ferreira and Vilela (2004), who termed dividends as alternate of cash. In times of financial distress, dividends can be manipulated (lowered or terminated) to generate cash for fulfilling financial obligations or internally financing the investments. Similarly, in Table 5, following estimation results of two-way fixed effects methodology, there is also a negative relationship between dividend payment and cash holdings of travel and leisure sector.

\subsubsection{Stock exchange}

In Table 9, the negative coefficient of stock exchange dummy (STEX) confirms H10. The negative impact of Stock exchange dummy on cash holdings shows that companies listed on Main-LSE hold less cash than the one listed on AIMLSE and ISDX. This finding is in line with the notion that companies listed on MainLSE are normally larger in size and have easier access to domestic and international capital markets. However, in Table 5, following the estimation results of two- way fixed effects methodology, there is a positive effect of STEX on cash holdings and also validates H10. As the travel and leisure sector typically not only have high risk, 
high competitiveness, asset- and labor-intensiveness but also growth-prioritization, which may obligate companies in the Main Market to hold more cash as well.

Focusing on the results in Table 5 and Table 9, relative to the reference subsector of travel and tourism, companies in the airlines sub-sector (Airlines) hold more cash, as the fundamental characteristics of the airlines sub-sector include higher risk due to highly volatile oil prices, higher fixed costs, and being highly cyclical (e.g., Keynes, 2009). The performance of airlines sector is immensely sensitive to changes in economic conditions (Bodie et al., 2011, p. 320), it must keep more cash. Similarly, larger airlines companies tend to pay more cash compensations to the chief executive officers ( $\mathrm{Gu}$ and Kim, 2009) and need to hold more cash. However, in Table 5, following the estimation methodology of two-way fixed effects, companies in the hotels (Hotels) and restaurants and bars (Restaurants and Bars) sub-sectors hold less cash than the one in the reference sub-sector. The fundamental features of hotels and restaurant and bars sub-sectors are that they are more cyclical and are more capital and labor-intensive, therefore making cash holdings an acute issue for these particular sub-sectors. Similarly, it is noted that the hotel sector finds it hard to obtain funds in bulk (Carrilio-Hidalgo and Pulido-Fernandez, 2016) and needs to have higher profitability to cope with higher fixed costs (Graham and Harris, 1999). Similarly, it is observed that hotel and restaurant companies carry more tangible assets such as land and buildings (Jang and Ryu, 2006). Due to the intense competition in these sub-sectors, managers are under constant pressure to pursue new projects and ventures (Chathoth and Olsen, 2007). In Table 9, cash holdings of companies in gambling (Gambling), hotels (Hotels), restaurants and bars (Restaurants and Bars) and recreational services (Recreational Services) sub-sector are not statistically different than the cash holdings of the reference sector. Similarly, 
in Table 5, cash holdings of companies in gambling (Gambling) and recreational services (Recreational Services) sub-sector are not statistically different than the cash holdings of the reference sector.

Focusing on the results in Table 5, relative to the reference year of 2005, the positive coefficients of 2014, 2015 and 2016 show that travel and leisure companies hold more cash in these three years than in year 2005 (i.e., in the years after the global financial crisis during 2008 and 2009). Moreover, the years 2006 to 2013 are found to have statistically insignificant impact on cash holdings of UK travel and leisure companies. Empirically, the study does not find any adverse effect on the cash holdings during the crisis years of 2008 and 2009. 


\section{Chapter 6}

\section{CONCLUSIONS}

Considering the unique fundamental characteristics of high leverage, high risk, high capital intensity and high competition in the TL sector, this study investigates the determinants of cash holdings for publicly traded companies operating in the UK travel and leisure sector and its six sub-sectors from 2005-2016. In line with the literature on cash holdings, ten company specific determinants are used: size, leverage, capital expenditures, growth opportunities, liquidity, cash flow, asset intangibility, cash flow volatility, dividend payments and stock exchange.

Following the generalized method of moments (GMM) methodology, the estimation results show that size, growth opportunities and cash flow positively affect the cash holdings of UK travel and leisure companies, while leverage, capital expenditures, liquidity, cash flow volatility, dividend payment and stock exchange exert a negative effect. Following the estimation methodology of two-way fixed effects, growth opportunities, cash flow, cash flow volatility and stock exchange positively affect the cash holdings of UK travel and leisure companies, while size, leverage, liquidity, asset intangibility, and dividend payment exert a negative effect.

Unlike two-way fixed effects estimation results, the estimation results of generalized method of moments (GMM) show that size positively affects cash holdings, while cash flow volatility and stock exchange negatively affect cash holdings. Moreover, following the estimation results of generalized method of moments (GMM), capital expenditures negatively affects cash holdings, while asset 
intangibility is statistically insignificant. Similarly, following the estimation results of two-way fixed effects, asset intangibility negatively affects cash holdings, while capital expenditures is statistically insignificant.

These empirical findings of determinants have practical implications for both managers and shareholders of UK travel and leisure sector. According to estimation results of both generalized method of moments (GMM) and two-way fixed effects, the companies in the airlines sub-sector hold more cash than the ones in the reference sub-sector of travel and leisure. However, following the estimation results of twoway fixed effects methodology, hotels and restaurants and bars companies hold less cash than the ones in the travel and tourism sub-sector. Furthermore, based on the estimation results of two-way fixed effects methodology, the results also suggest that travel and leisure companies are holding more cash in the years 2014, 2015 and 2016 relative to the reference year 2005 (i.e., after the global financial crisis in 2008 and 2009). In the study, no empirical evidence has been found showing the impact of the global financial crisis on the cash holdings of travel and leisure sector.

The academic implications of the study strongly support the pecking-order model, followed by the trade-off model to explain cash holdings in travel and leisure sector. Larger travel and leisure companies hold less cash due to less financial distress. Moreover, these larger companies have lower cost of external financing due to less information asymmetry, which is consistent with pecking-order theory. Similarly, travel and leisure companies with more leverage tend to hold less cash not only due to being closely monitored but also due to their easier access to debt markets. Further, travel and leisure companies with more growth opportunities tend to hold more cash to fund future profitable projects and to avoid liquidity shortages, which supports the precautionary motive. Supporting the trade-off model, travel and 
leisure companies with more cash flows tend to hold more cash to fund prospective projects and to alleviate the risk in future uncertainties as well. Dividends can be manipulated (lowered or terminated) to generate cash for fulfilling financial obligations or investing in profitable investments. There is weak support for the free cash flow model in the financially constrained travel and leisure sector.

The empirical findings of this study also have practical implications for both managers and shareholders of travel and leisure sector of UK. Cash holdings managerial decisions are a potential source of conflict between managers and shareholders. The results help the investors of the travel and leisure sector to grasp the cash management decisions of managers (insiders). For instance, by utilizing the empirical findings in this study, an investor sensitive to empire-building traits of managers for their private benefits, can infer that large travel and leisure corporations with more leverage and capital expenditures will hold less cash. These features will guide such concerned investors to opt for travel and leisure corporations holding less cash, who depend considerably on debt or internal funds, thereby regulating malpractices of managers dealing cash. However, holding excessive cash in such corporations can create agency problems. However, large travel and leisure corporations holding more cash would have an ease in practicing debt financing as holding more cash is an indication of rash diversification and expansion, making shareholders more heedful about their net earnings. In order to curtail the deleterious effect of asymmetric information between management of travel and leisure corporations and its stakeholders (shareholders and lenders), managers not only need to understand the determinants of cash holdings but also have to devise pragmatic line of action representing corporation's real inside. Moreover, the empirical findings of this study also have some policy implications for the travel and leisure sector of 
UK. For instance, it has been confirmed that travel and leisure companies of UK are financially constrained. Therefore, the government may come up with more new and improved policies to help the travel and leisure sector to overcome the financial constraints, which is already injecting significant amount of revenue into the UK economy. Finally, this study enriches the literature on the corporate cash holdings by examining a sector with its unique characteristics and paves the way for doing further research for such companies in other countries. 


\section{REFERENCES}

Al-Najjar, B., and Belghitar, Y. (2011). Corporate cash holdings and dividend payments: Evidence from simultaneous analysis. Managerial and Decision Economics, 32(4), 231-241. doi:10.1002/mde.1529

Antonio, F., Kadyrzhanova, D., Jae W., and Sim, J. W. (2013). Rising intangible capital, shrinking debt capacity, and the US corporate savings glut. Federal Reserve Board working paper. doi:10.2139/ssrn.2350863

Arellano, M., and Bond, S. (1991). Some Tests of Specification for Panel Data: Monte Carlo Evidence and an Application to Employment Equations. Review of Economics Studies, 58, 277-97. doi:10.2307/2297968

Arellano, M. and Bover, O. (1990). La Econometria de Datos de Panel, Investigaciones Economicas, 14, 3-45.

Arellano, M. and Bover, O. (1995). Another look at the instrumental variable estimation of error-components models. Journal of Econometrics, 68, 29-51.

Baltagi, B. H. (2005). Econometric analysis of panel data ( $3^{\text {rd }}$ ed.). England: Wiley.

Bates, T. W., Kahle, K. M., and Stulz, R. M. (2009). Why do US firms hold so much more cash than they used to? The Journal of Finance, 64 (5), 1985-2021. doi:10.1111/j.1540-6261.2009.01492.x 
Berk, J., and DeMarzo, P. (2014). Corporate Finance. 3. uppl. Harlow: Pearson Education.

Bigelli, M., and Sanchez-Vidal, J. (2012). Cash holdings in private firms. Journal of Banking \& Finance, 36, 26-35. doi:10.1016/j.jbankfin.2011.06.004

Blundell, R., and Bond, S. (1998). Initial conditions and moment restrictions in dynamic panel data models. Journal of Econometrics 87, 115-143.

Bodie, Z., Kane, A., and Marcus, A. J. (2011). Investments $\left(9^{\text {th }}\right.$ ed.). New York, NY: McGraw-Hill.

Carrilio-Hidalgo, I., and Pulido-Fernandez, J. I. (2016). Is the financing of tourism by international financial institutions inclusive: A proposal for measurement? Current Issues in Tourism. doi:10.1080/13683500.2016.1260529

Chathoth, P. K., and Olsen, M. (2007). Does corporate growth really matter in the restaurantindustry? International Journal of Hospitality Management, 26 (1), 66-80. doi:10.1016/j.ijhm.2005.09.004

Colquitt, L. L., Sommer, D. W., and Godwin, H. N. (1999). Determinants of cash holdings by property-liability insurers. The Journal of Risk and Insurance, 66 (3), 401-415. doi:10.2307/253554 
Dalbor, M. C., and Upneja, A. (2007). An examination of dividend policy in the US restaurant industry. Journal of Foodservice Business Research, 10 (2), 83-91. doi:10.1300/j369v10n02_06

D’Mello, R., Krishnaswami, S., and Larkin, P. J. (2008). Determinants of corporate cash holdings: Evidence from spin-offs. Journal of Banking and Finance, 32 (7), 1209-1220. doi:10.1016/j.jbankfin.2007.10.005

Dewally, M., Shao, Y., and Singer, D. (2013). The liquidity crisis: evidence from the US hospitality industry. Tourism Economics, $19 \quad$ (3), 545-563. doi:10.5367/te.2013.0214

Dogru, T., and Sirakaya-Turk, E. (2017). The value of cash holdings in hotel firms. International Journal of Hospitality Management, 65, 20-28. doi:10.1016/j.ijhm.2017.05.004

Drobetz, W., and Grüninger, M. C. (2007). Corporate cash holdings: Evidence from Switzerland. Financial Markets Portfolio Management, 21, 293-324. doi:10.1007/s11408-007-0052-8

Easterbrook, F. H. (1984). Two agency-cost explanations of dividends. The American Economic Review,74 (4), 650-659. 
Ferreira, M. A., and Vilela, A. S. (2004). Why do firms hold cash: Evidence from EMU countries? European Financial Management, 10 (2), 295-319. doi:10.1111/j.1354-7798.2004.00251.x

García-Teruel, P., and Martínez-Solano, P. (2008). On the determinants of SME cash holdings: Evidence from Spain. Journal of Business Finance \& Accounting, 35, 127-149. doi:10.1111/j.1468-5957.2007.02022.x

Graham, I. C., and Harris, P. J. (1999). Development of a profit planning framework in an international hotel chain: A case study. International Journal of Contemporary Hospitality Management, $11 \quad$ (5), 198-204. doi:10.1108/09596119910272694

Griffiths, M. D., and Parke, J. (2002). The social impact of internet gambling. Social Science Computer Review, 20, 312-320. doi:10.1177/089443930202000308

Gu, Z., and Kim, H. (2009). CEO cash compensation determinants: an empirical examination of US airlines. The Service Industries Journal, 29(7), 995-1005. doi:10.1080/02642060902749823

Gursoy, D., and Swanger, N. (2007). Performance-enhancing internal strategic factors and competencies: impacts on financial success. International Journal of Hospitality Management, 26 (1), 213-227. doi:10.1016/j.ijhm.2006.01.004 
Gujarati, D., and Porter, D. (2009). Basic econometrics, (5 ${ }^{\text {th }}$ ed.). New York, NY: McGraw-Hill.

Han, S., and Qiu, J. (2007). Corporate precautionary cash holdings. Journal of Corporate Finance, 13, 43-57. doi:10.1016/j.jcorpfin.2006.05.002

Hansen, L. (1982). Large sample properties of generalized methodof moments estimators, Econometrica, 50, 1029-54.

Hardin, W. G., Highfield, M. J., Hill, M. D., and Kelly, W. (2009). The determinants of REITcash holdings. Journal of Real Estate Financial Economics, 39 (1), 3957. doi:10.1007/s11146-007-9103-1

Holthausen, R. W., and Watts, R. L. (2001). The relevance of the value-relevance literature for financial accounting standard setting. Journal of Accounting and Economics, 31(1-3), 3-75. doi:10.1016/s0165-4101(01)00029-5

Islam, S. (2012). Manufacturing firms' cash holding determinants: Evidence from Bangladesh. International Journal of Business and Management, 7 (6), 172184. doi:10.5539/ijbm.v7n6p172

Ip, C., Leung, R., and Law, R. (2011). Progress and development of information and communication technologies in hospitality. International Journal of Contemporary Hospitality $\quad$ Management, 23(4), 533-551. doi:10.1108/09596111111130029 
Jensen, M. C. (1986). Agency costs of free cash flow, corporate finance and takeovers. American Economic Review, 76, 323-339.

Jensen, M. C., and Meckling, W. (1976). Theory of the firm: managerial behaviour agency costs and ownership structure. Journal of Financial Economics, 30 (4), 474-493. doi:10.1016/0304-405x(76)90026-x

Karadeniz, E., Yilmaz Kandir, S., Balcilar, M., and Beyazit Onal, Y. (2009). Determinants of capital structure: evidence from Turkish lodging companies. International Journal of Contemporary Hospitality Management, 21 (5), 594-609. doi:10.1108/09596110910967827

Kang, S. (1985). A note on the equivalence of specification tests in the two-factor multivariate variance components model. Journal of Econometrics, 28, 193203. doi:10.1016/0304-4076(85)90119-8

Keynes, J. 2009. "Characteristics of the Airline Industry." In A. Cento (Ed.), The Airline Industry: Challenges in the 21st Century 13-44. Berlin: Springer-Verlag. doi: 10.1007/978-3-7908-2088-1_2

Kim, H., and Gu, Z. (2009). Financial features of dividend-paying firms in the hospitality industry: A logistic regression analysis. International journal of Hospitality Management, 28(3), 359-366. doi:10.1016/j.ijhm.2008.12.003 
Kim, J., Kim, H., and Woods, D. (2011). Determinants of corporate cash-holding levels: An empirical examination of the restaurant industry. International Journal of Hospitality Management, $30, \quad 568-574$. doi:10.1016/j.ijhm.2010.10.004

Kim, J., Woods, D., and Kim, H. (2013). Identifying the financial characteristics of cash-rich and cash-poor restaurant firms: A logistic regression analysis. Tourism Economics, 19 (3), 583-598. doi:10.5367/te.2013.0217

Kwansa, F. A., Johnson, D., and Olsen, M. (1987). Determinants of financial structure in the hotel industry and implications for the teaching of financial management in the hospitality industry. Hospitality Education and Research Journal, 10 (2), 99-106.

Lian, Y., Sepehri, M., and Foley, M. (2011). Corporate cash holdings and financial crisis: An empirical study of Chinese companies. Eurasian Business Reviews, 1 (2), 112-124.

Lee, E., and Powell, R. (2011). Excess cash holdings and shareholder value. Journal of Accounting \& Finance, 51, 549-574. doi:10.1111/j.1467-629x.2010.00359.x

Lev, B. (2000). Intangibles: Management, measurement, and reporting. Brookings Institution Press. 
Martínez-Sola, C., Garcia-Teruel, P. J and Martínez-Solano, P. (2011). Corporate cash holding and firm value. Applied Economics, 45 (2), 161-170. doi:10.1080/00036846.2011.595696

Maheswari, Y., and Rao, K. T. V. (2017). Determinants of corporate cash holdings. Global Business Review, 18 (2), 416-427. doi:10.1177/0972150916668610

Minton, B. A., and Schrand, C. (1999). The impact of cash flow volatility on discretionary investment and the costs of debt and equity financing. Journal of Financial Economics, 54 (3), 423-460. doi:10.1016/s0304-405x(99)00042-2

Mung, S. G., and Jang, S. (2015). Working capital, cash holding and profitability of restaurant firms. International Journal of Hospitality Management, 48, 1-11. doi:10.1016/j.ijhm.2015.04.003

Myers, S. C., and Majluf, N. S. (1984). Corporate financing and investment decisions when firms have information that investors do not have. Journal of Financial Economics, 13, 187-221. doi:10.1016/0304-405x(84)90023-0

Nakamura, L. I. (2001). Investing in intangibles: is a trillion dollars missing from the GDP? Business Review, (4), 27-36. doi:10.1016/b978-0-7506-7773-8.50008-x

Opler, T., Pinkowitz, L., Stulz, R., and Williamson, R. (1999). The determinants and implications of corporate cash holdings. Journal of Financial Economics, 52 (1), 3-46. doi:10.1016/s0304-405x(99)00003-3 
Ozkan, A., and Ozkan, N. (2004). Corporate cash holdings: An empirical investigation of UK companies. Journal of Banking and Finance, 28 (9), 21032134. doi:10.1016/j.jbankfin.2003.08.003

Parke, A., and Griffiths, M. D. (2004). Why internet gambling prohibition will ultimately fail? Gaming Law Review, 8, 297-301. doi:10.1089/glr.2004.8.295

Paskelian, O. G., Bell, S., and Nguyen, C. V. (2010). Corporate governance and cash holdings: a comparative analysis of Chinese and Indian firms. The International Journal of Business and Finance Research, 4, 59-73.

Pastor, C. C., and Gama, P. M. (2013). Determinant factors of cash holdings: Evidence from Portuguese SMEs. International Journal of Business and Management, 8 (1), 104-112. doi:10.5539/ijbm.v8n1p104

Peterson, M., and Rajan, R. (2002). Does distance still matter: The information revolution in small business lending? The Journal of Finance, 57 (6), 25332570. doi:10.1111/1540-6261.00505

Riddick, L. A., and Whited, T. M. (2009). The corporate propensity to save. The Journal of Finance, 64 (4), 1729-1766. doi:10.1111/j.1540-6261.2009.01478.x

Reich, A. Z. (1993). Applied economics of hospitality production. International Journal of Hospitality Management, 12 (4), 337-352. doi:10.1016/02784319(93)90050-j 
Singal, M. (2015). How is the hospitality and tourism industry different? An empirical test of some structural characteristics. International Journal of Hospitality Management, 47, 116-119. doi:10.1016/j.ijhm.2015.03.006

Sheel, A. (1994). Determinants of capital structure choice and empirics on leverage behavior: A comparative analysis of hotel and manufacturing firms. Hospitality Research Journal, 17 (3), 1-16. doi:10.1177/109634809401700302

Sheel, A. (1998). The relationship between dividend yields and common equity returns for hotel and lodging firms in the United Kingdom, the United States, and Japan: some empirical evidence. Journal of Hospitality \& Tourism Research, 22 (1), 84-97. doi:10.1177/109634809802200108

Shleifer, A., and Vishny, R. W. (1992). Liquidation values and debt capacity: A market equilibrium approach. The Journal of Finance,47(4), 1343-1366. doi:10.1111/j.1540-6261.1992.tb04661.x

Stock, J. H., and Watson, M. W. (2003). Introduction to econometrics. New York, NY: Addison Wesley.

Upenja, A., and Dalbor, M. C. (2001). An examination of capital structure in the restaurantindustry. International Journal of Contemporary Hospitality Management, 13(2), 54-59. doi:10.1108/09596110110381825 
Uyar, A., and Kuzey, C. (2014). Determinants of corporate cash holdings: Evidence fromemerging market of Turkey. Applied Economics, 46 (9), 10351048.doi:10.1080/00036846.2013.866203

Verbeek, M. (2008). A guide to modern econometrics. 3rd Edition. Chichester, England:John Wiley \& Sons, Ltd.

Williamson, O. (1988). Corporate finance and corporate governance. The Journal of Finance, 43 (3), 567-591. doi:10.1111/j.1540-6261.1988.tb04592.x

Wooldridge, J.M. (2002). Econometric Analysis of Cross Section and Panel Data. MIT Press, Cambridge. 